[Vicino Oriente XXIV (2020), pp. 1-26]

\title{
AN EGYPTIAN GREEN SCHIST PALETTE AND AN AMAZONITE GEMSTONE FROM THE "PALACE OF THE COPPER AXES" AT BATRAWY, JORDAN
}

\author{
Lorenzo Nigro $^{+}$- Elisabetta Gallo ${ }^{+}$- Romeel Gharib ${ }^{\S-}$ Francesco Mura ${ }^{*}$ - Michele Macrì ${ }^{\times}$ \\ Teresa Rinaldi ${ }^{\dagger}$ \\ Sapienza University of Rome \\ Ministry of Tourism and Antiquities of the Hashemite Kingdom of Jordan ${ }^{1}$
}

\begin{abstract}
The exploration of the "Palace of the Copper Axes", the Early Bronze Age III palace of the

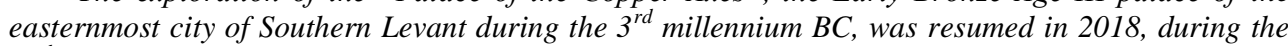
$14^{\text {th }}$ season of excavation at Khirbet al-Batrawy in north-central Jordan, and completed in 2019. In the entrance hall of the palace, a square space with ceilings supported by four pillars, an Egyptian green schist palette, a cyan gemstone of amazonite and a pierced bead of fluorapatite were found buried under the destruction layer, while a barrel-shaped carnelian bead from Mesopotamia was found in the destruction layer just outside the Eastern Pavilion of the palace. These finds again testify to the inclusion of the palace and the city into a wide international trade network and its special connections with Pharaonic Egypt. ${ }^{2}$
\end{abstract}

Keywords: palette; Egypt; Batrawy; "Palace of the Copper Axes"; amazonite

\section{THE FINDING CONTEXT: ENTRANCE HALL L.1100}

In October 2018 and 2019, Sapienza University Expedition to Palestine \& Jordan carried out the $14^{\text {th }}$ and $15^{\text {th }}$ seasons of excavations and restorations at the site of Khirbet alBatrawy, in north-central Jordan, concluding the exploration of the "Palace of the Copper Axes". ${ }^{3}$ The excavation of the building continued towards west, where the existence of an entrance hall had been surmised: the plan of the palace is clearly organized according to a symmetrical layout with a central entrance separating two wings (fig. 1).

Department of Italian Institute of Oriental Studies, Sapienza University of Rome.

Zarqa Directorate, Department of Antiquities of the Hashemite Kingdom of Jordan.

Department of Astronautics Engineering, Electrical and Energy, Sapienza University of Rome.

Department of Earth Sciences, Sapienza University of Rome.

Department of Biology and Biotechnology "Charles Darwin", Sapienza University of Rome.

$\S 1$. is written by L.N. - E.G. - R.G.; § 2. by L.N. - E.G.; § 3. by F.M. - T.R.; § 4. by L.N. - E.G. - F.M.; 55 by L.N. - E.G. - M.M.; $\S 6$. by L.N. Excavations at Khirbet al-Batrawy were supported by Sapienza University of Rome, the Italian Ministry of Foreign Affairs and International Cooperation, and the Department of Antiquities of Jordan. Our deepest thanks are addressed to the Academic Authorities of Sapienza, Prof. Alessandra Brezzi, Director of the Department of Oriental Studies, and Dr. Angela Gazzillo; H.E. Fabio Cassese, the Italian Ambassador to Jordan, H.E. Dr. Yazid Elayan, the General Director of Department of Antiquities of the Hashemite Kingdom of Jordan, and Dr. Aktham Oweidi, Director of Excavations \& Surveys.

Nigro 2014a.

The final report on the excavation of the palace, in seasons 2009-2012 and 2017-2019, is going to appear in 2020. Provisional information on stratigraphy, architecture and finds is available in the following publications: Medeghini - Nigro 2017; Medeghini et al. 2016; Nigro 2010a; 2010b; 2010c; 2010d; 2011; 2012a; 2012b; 2012c; 2013a; 2013b; 2014a; 2014b; 2014c; 2015; 2016; Nigro ed. 2008, 127-240; 2012, 145332; Nigro - Sala 2010; 2011; 2012; 2013.

ISSN 0393-0300

e-ISSN 2532-5159

Rivista Open Access 


\subsection{Stratigraphy}

Two occupational phases of the Early Bronze Age $\mathrm{IVB}^{4}$ were distinguished just over an earliest reuse of the burnt ruins of the palace and its furnishings, which can be ascribed to the end of the Early Bronze Age IVA. Nonetheless, the underlying destruction strata were up to $1 \mathrm{~m}$ thick, due to the slope of the bedrock, and basically consisted of an upper layer (F.1324), incorporating collapsed building material, and a lower layer (F.1327), consisting of burnt ceilings fallen down on the floor (L.1330) of the entrance hall. The upper layer included fragments of yellowish-clay plaster (some with reeds impressions), charcoals, ashes, broken mud-bricks, stones, and several items apparently fallen down from the upper storey, roofing or balconies (fig. 2). The lower layer consisted of brownish-gray soil, with ashes and charcoals, and sealed finds smashed on the original floor of the hall.

Both layers mark the end of Period Batrawy IIIb (Early Bronze Age IIIB), when the city was set on fire and the palace transformed into a heap of ruins; according to radiocarbon, this event is dated back around the mid of the $3^{\text {rd }}$ millennium BC. ${ }^{5}$

\subsection{Architecture: Entrance Hall L. 1100}

The investigated area was considered the entrance hall of the palace, called L.1100 (fig. $3)^{6}$ It was delimited by Walls W.1103+W.1133, to the east; Wall W.1245, to the south; and Walls W.1323+W.1333, to the west. The last two walls were also the eastern limit of Hall L.1340, the northern room of the western wing of the palace arranged symmetrically to Pillared Hall L.1040 and completely explored during the 2019 season.

Underneath the thick destruction layer, four stone bases $0.2 \mathrm{~m}$ high, symmetrically displaced, have been uncovered. ${ }^{7}$ They were the bases of wooden pillars supporting the at least $3.5 \mathrm{~m}$ high roof of Entrance Hall L.1100. The bedrock pavement of the hall was uncovered in the southern upper part of the hall, while in the centre and to the north the floor (L.1330), consisted of a compact layer of yellowish marl and crushed limestone, laid over a marl-pebbles preparation and a filling regularizing the bedrock surface.

The entrance hall opened to the north towards the street (L.1060) running along the citywalls, and was flanked by the northernmost rooms of the palace (Halls L.1040 and L.1340), while to the south a raised porch (L.1292) connected it with a second line of large rooms (L.1110 and L.1250). The four pillars monumentalized the space and distributed circulation between four symmetrical doors, two on the eastern side and two on the western side of the

\footnotetext{
Nigro ed. 2012, 146, tab. 3.1.

Radiocarbon dates so far published from the EB IIIB contexts of the palace (Höflmayer 2014, 130, figs. 3-4) and further dates being published, though earlier from about two centuries to one century than traditional chronology, provide an indication of the possible end of the EBA city of Batrawy which does not necessarily imply a raising of the end of the Early Bronze III in the Southern Levant, a phenomenon which occurred not simultaneously in the various sites of the region (Nigro 2017, 165-166).

6 In season 2018 works in the area of the palace included the eastern half of Square B1II5 and Squares B1III6-7 (see Nigro 2016, fig. 2). In season 2019, excavations continued towards west in Squares BkII5+B1II5.

B.1285 (NE pillar base), B.1329 (SE pillar base), B.1331 (NW pillar base), B.1339 (SW pillar base). As in Hall L.1040 (Nigro 2016, 142, fig. 9), bases were limestone boulders, laid on small stones set into the bedrock.
} 
hall, which gave access to two facing wings of the palace. Pillars and doors were placed in order not to hamper circulation and to emphasize the palace monumentality (fig. 4).

\subsection{Finds from Entrance Hall L.1100}

On the floor and within the destruction layers in Entrance Hall L.1100 several finds were collected, some of them originally deposited on the floor of this room, while the majority fallen down from the upper storey or balconies during the collapse of the burning palace.

At least two big pithoi, ${ }^{8}$ one jar, ${ }^{9}$ one amphoriskos ${ }^{10}$ and a small bottle ${ }^{11}$ were found in the hall. The two pithoi are made of different fabrics and with different manufacture quality, one (KB.18.B.1324/1) is preserved only in the lower half, the other (KB.18.B.1324/3) is complete and has a rope-like decoration at the bottom of the neck. Pithos KB.18.B.1324/1 was found leaning against the western wall of the hall, Wall W.1323, ${ }^{12}$ pithos KB.18.B.1324/3 was found next to the north-eastern pillar base (B.1285), while the other vessels mentioned above were found in the middle of the hall, just east of the same wall, W.1323.

A large amount of items was found together with pottery vessels, some of them related to daily activities (flint blades, ${ }^{13}$ mortars, ${ }^{14}$ and a pestle ${ }^{15}$ ), others to craft activities (polishing pebbles ${ }^{16}$ and bone tools ${ }^{17}$ ), others simply linked to the economic and political role played by the palatial institution. ${ }^{18} \mathrm{~A}$ pit (P.1326) full of plaster and clayish marl, including the clay fragments with impressed reeds, ${ }^{19}$ was uncovered in the south-western

KB.18.B.1324/1 and KB.18.B.1324/3. Pithoi for long-term conservation were particularly frequent in the palace and characterized by an elongated ovoid body and flaring neck, a narrow flat base, and rope-like plastic decorations usually applied at the junction of the different parts of the vessel, at the base of the neck and on the middle of the body (Nigro 2016, 142-143; Sala 2014a, 268, figs. 16-17).

9 KB.18.B.1324/25.This specimen belongs to the category of the medium size jars for daily deposit, with a squat ovoid body, flaring neck, short everted rim, and a couple of pushed-up ledge handles applied on the middle of the body (Sala 2014a, 267, fig. 12).

10 KB.18.B.1324/24. The amphoriskos belongs to the sub-type with slender body and a cylindrical neck, similar to other specimens found in the palace (Sala 2014a, 267, fig. 11:5).

11 KB.18.B.1324/26.

12 Pithos KB.18.B.1324/1 contained the burnt epiphysis of a bovine homer (KB.18.B.FR.24) and a quartzite pear-shaped pestle (KB.18.B.32).

13 Flint implements are three Canaanean blades (KB.18.B.21, KB.18.B.38, KB.18.B.51), and one flint sickle (KB.18.B.40).

14 KB.18.B.34, KB.18.B.36, KB.18.B.62. Limestone mortar KB.18.B.34 was perhaps a re-employed doorsocket.

KB.18.B.32

16 KB.18.B.31, KB.18.B.37, KB.18.B.41, KB.18.B.48.

17 Bone tools are a carefully polished awl (KB.18.B.28.) and a sort of stylus (KB.18.B.25)

18 Three pottery tokens (or stoppers) were found close to each other (KB.18.B.26, KB.18.B.27, KB.18.B.22), possibly used as administrative tools/counters.

19 KB.18.B.AR.8 
corner of the hall. On the northern edge of the destruction layer, ${ }^{20}$ a circular burnt mark in the soil may indicate the original presence of a wooden basket.

One of the most remarkable items was found in the north-eastern quadrant of the hall. Exactly at the interface of the upper and lower layers of destruction, just aside the foot of the north-eastern pillar base (B.1285), where the large pithos KB.18.B.1324/3 was smashed on the floor, a broken Egyptian green schist palette was found upside down in the yellowish bricky layer, probably fallen from an upper storey or balcony (figs. 5-6). Finally, at the foot of the south-western pillar base (B.1339) an amazonite gemstone and a small bead of fluorapatite were found on the floor of the hall.

All these finds depict the ordinary life of the palace as a place of exchange, transformation and gathering of different goods including luxury and imported items.

\section{THE GREEN SCHIST PALETTE (KB.18.B.30)}

The green schist palette (KB.18.B.30) was originally rectangular in shape, with the approximate dimensions of a modern smartphone $(10 \times 9.7[15] \mathrm{cm}, 0.9-1.2 \mathrm{~cm}$ thick), and only the upper left part is preserved (fig. 7). It was carved in the finest Egyptian style, with a double-line grooved frame all around it and a slightly convex shape tapering towards the edges (fig. 8).

\subsection{Type and material}

The palette belongs to the square/rectangular type, around $1 \mathrm{~cm}$ thick, with a grooved frame of one or at least three incised lines on the polished front side. This type, commonly attested in Egypt since the early Naqada III period, ${ }^{21}$ is imported to the Southern Levant during the Early Bronze Age IB-III.22 Similar specimens had been found at other EBA III sites, such as Tell el-Khuweilifeh/Tel Halif ${ }^{23}$ and Khirbet Kerak/Beth Yerah. ${ }^{24}$ East of the Jordan River, Egyptian palettes had been found at Bab edh-Dhra ${ }^{25}$ Numeira, ${ }^{26}$ Tell el-

20 Here, destruction layer F.1327 was cut by pit P.865 of Phase 1, the filling of which (F.864) contained several animal bones (KB.18.B.FR.18 and KB.18.B.FR.27) and Islamic pottery fragments related to a later frequentation of the site, used as a quarry for building materials.

21 Petrie 1974, 38, pl. LIX; Stevenson 2009, fig. 6. In Naqada III period palettes became progressively rare, and next to the typical rectangular palette, ceremonial palettes skilfully carved with elaborate reliefs were used as status insigna of the emerging kingship (Petrie 1953), as the most famous specimen, the Narmer Palette, testifies to.

22 Together with stone maceheads and calcite vessels, cosmetic palettes represent one of the most frequent luxury goods imported from Egypt to the Southern Levant during the $3^{\text {rd }}$ millennium BC (Sala 2012, 277-279 2014b, 66-67). The presence of Egyptian outposts and Egyptian merchants travelling along the Southern Levant allowed the establishment of a steady trade network between the Pharaonic Kingdom and the protourban Southern Levantine centers already during the Early Bronze Age IB (de Miroschedji et al. 2001; de Miroschedji 2002, 41-45; Braun - van den Brink 2008, 659-672; Braun 2011, 112-119; 2014, 39-40). The rise of the urban society in the Early Bronze Age II-III encouraged the development of new forms of relationships and Egyptian luxury goods became symbols of power of the emerging Southern Levantine élites and objects not only of commerce but also of diplomacy (de Miroschedji 2002, 45-47; Greenberg - Eisenberg 2002, 214 221; Greenberg et al. 2012, 96; Sowada 2009, 36-37, 109, 127).

23 Jacobs 1996; Jacobs - Seger 2017, 87-88, fig. 2.B.26

24 Greenberg - Eisenberg 2002, 214, fig. 13.2; Sowada 2009, 121-122.

25 Rast - Schaub 1989, 343, 384-385; 2003, 294, 400, figs. 10.39:2, 12.6:3-4; Wilkinson 1989, 454-455, figs 261:3, 261:7; Lee 2003, 631; Sowada 2009, 95-97, fig. 18, pl. 13 
'Umeiri, ${ }^{27}$ and during the exploration of the village of Umm Saysabān in the region of Petra. ${ }^{28}$ Finally, a further specimen came right from the "Palace of the Copper Axes" of Batrawy, where the first Egyptian palette (KB.11.B.100) was found in 2011 season in the south-western corner of Pillared Hall L. $1040 .^{29}$

The X-Ray diffraction pattern (fig. 9) revealed that the palette has the typical mineral composition of green talc-schist, which was extracted in Egypt from quarries in the Eastern Desert. ${ }^{30}$ It is mainly constituted by quartz, orthoclase, chlorite and muscovite, and its texture is fine and the hardness is very low (1.2 of Mohs' scale). The results obtained by XRay diffraction are confirmed by the EDX map performed in the area shown in fig. 10 (image at the top), where the presence of titanium grains, zirconium silicate and aluminium silicate, containing small quantities of iron, were revealed.

\subsection{Traces of use}

Several scratches are visible on the surfaces of the palette, produced with wooden or bone tools used to mix and prepare the makeup powders (fig. 11). Due to the softness of the stone these scratches may have been produced also by sharpened nails.

Some coloured spots have been identified to be analyzed in order to check the possibility that they concealed traces of the original products used as cosmetics (§3.).

\section{ANALYSES OF COSMETIC REMAINS ON THE PALETTE}

Three different spots on the surfaces of the palette have been sampled in the Biology and CNIS Labs of Sapienza University, plus one not-stained area as comparison, and underwent three different methods of analyses aiming to characterize the chemical-physical composition of such traces.

\section{1. $S E M \& E D X$}

The area containing the coloured spots has been gently scratched using a scalpel, and the powder has been mounted over SEM stub by a conductive graphite tape. A stratigraphy of the palette has been done analyzing a polished cross-section of a micro fragment embedded in an acrylic resin. All the images have been obtained using an Auriga Zeiss FESEM, equipped with a Bruker Quantax Microanalysis (energy resolution $123 \mathrm{eV} \mathrm{K \alpha}$ $\mathrm{Mn})$.

\subsection{X-Ray diffraction}

XRD pattern has been acquired using a Philips Analytical PW1830 X-Ray diffractometer, equipped with $\mathrm{Ni} \beta$-filtered $\mathrm{Cu}-\mathrm{K} \alpha 1$ (1.54056 $\AA$ ) radiation, in the $2 \theta$ range from 5 to $80^{\circ}$ with a step size of $0.02^{\circ}$ and a time for step of $3.5 \mathrm{sec}$.

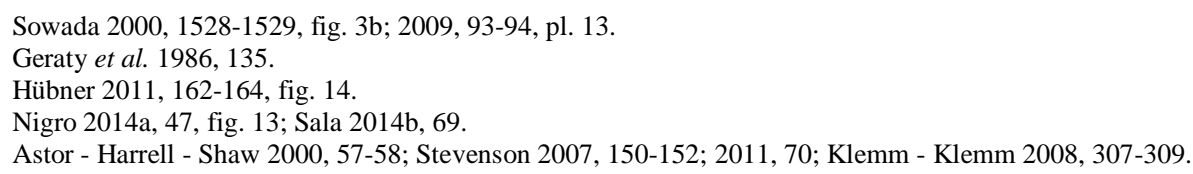


The data were collected with an acceleration voltage and applied current respectively of $40 \mathrm{kV}$ and $30 \mathrm{~mA}$. The crystalline phases in the resulting diffractogram have been identified through the COD database (Crystallography Open Database - an open-access collection of crystal structures). ${ }^{31}$

\subsection{Raman}

The Raman spectra have been recorded using a micro-Raman dispersive spectrometer (SENTERRA, Bruker Optik $\mathrm{GmbH}$ ), employing a $\mathrm{CW}$ diode pumped solid state laser of $100 \mathrm{~mW}$ operating at $785 \mathrm{~nm}$. The spectra have been recorded by using a $50 \times$ objective with a resolution of $3 \mathrm{~cm}^{-1}$ in the spectral window from 45 to $1500 \mathrm{~cm}^{-1}$.

\subsection{Results}

The preliminary analysis of the palette revealed the presence of coloured spots on its surfaces: the one located in the central area of the front side provided the following results.

A SEM analysis was performed, and through the back-scattered electron signal has been possible to locate micrometric iron oxide grains that, according to the EDX spectrum, correspond to red ochre (fig. 12). The ironloxygen ratio (tab. 1) is compatible with red ochre, despite the possible presence of aluminium silicates and titanium. The carbon signal derives from the graphite tape used for mounting the extracted powder of the palette. In order to distinguish between different forms of metal oxides, molecular spectroscopy analysis was also performed: the Raman spectrum (fig. 13) confirmed that the analyzed spot is red ochre. Raman analysis identified the red spot as bands of haematite $\left(\mathrm{Fe}_{2} \mathrm{O}_{3}\right)$ at 606,405 and $290 \mathrm{~cm}^{-1}$. The presence of titanium, which was found in traces as brookite $\left(\mathrm{TiO}_{2}\right)$, at 511 and $153 \mathrm{~cm}^{-1}$, could correspond to a contaminant of titanium dioxide phase in natural iron oxide deposits.

\begin{tabular}{|l|l|l|l|l|l|}
\hline El & AN & Series & norm. & C Atom. & C Error (1 Sigma) \\
\hline$[$ wt.\%] & [at.\%] & [wt.\%] & 1.35 \\
\hline $\mathrm{Fe}$ & 26 & K-series & 47.51 & 21.35 & 4.47 \\
\hline $\mathrm{O}$ & 8 & K-series & 36.59 & 57.39 & 1.47 \\
\hline $\mathrm{C}$ & 6 & K-series & 6.49 & 13.55 & 0.24 \\
\hline $\mathrm{Si}$ & 14 & K-series & 4.94 & 4.41 & 0.12 \\
\hline $\mathrm{Ti}$ & 22 & K-series & 1.81 & 0.95 & 0.12 \\
\hline $\mathrm{Al}$ & 13 & K-series & 1.75 & 1.62 & 0.06 \\
\hline $\mathrm{K}$ & 19 & K-series & 0.56 & 0.36 & 0.06 \\
\hline $\mathrm{Mg}$ & 12 & K-series & 0.36 & 0.37 & \\
\hline \multicolumn{7}{|c|}{ Total: } \\
\hline
\end{tabular}

Tab. 1 - EDX quantitative analysis of the red ochre grain.

31 Gražulis et al. 2009. 


\section{THE AMAZONITE GEMSTONE (KB.18.B.50) AND THE FLUORAPATITE BEAD (KB.18.B.63)}

A cyan gemstone (KB.18.B.50) in the shape of a rectangular parallepiped with smoothed edges and a tooth-like apex was uncovered almost over the floor of Entrance Hall L.1100 in the south-western corner of the hall (figs. 14-15). The gemstone is remarkably big $(3.0 \times 1.55-0.4 \times 1.3 \mathrm{~cm})$; its surfaces were partly polished and the edges smoothed. At the bottom and the tip, metallic veins are visible. Apparently the gem had been worked to become a major pendant in a necklace.

A very small pierced bead (KB.18.B.63) of a similar turquoise color was found not far from the gemstone (fig. 16); it shows a roughly square shape $(0.62 \times 0.58 \times 0.2 \mathrm{~cm})$ and an eccentric round hole $(0.18-0.20 \mathrm{~cm}$ of diameter). The bead is similar but not identical to those belonging to the necklace found in 2011 season in Hall L.1110. ${ }^{32}$

\subsection{Stone identification and interpretation}

The gemstone KB.18.B.50 and bead KB.18.B.63 have been identified through Raman spectrography.

Raman spectra have been recorded using a micro-Raman dispersive spectrometer (SENTERRA, Bruker Optik GmbH), employing a CW diode pumped solid state laser of 5 $\mathrm{mW}$ operating at $532 \mathrm{~nm}$. The spectra have been recorded by using a $20 \times$ objective with a resolution of $3 \mathrm{~cm}^{-1}$ in the spectral window from 45 to $1500 \mathrm{~cm}^{-1}$ and then compared with the mineral database RRUFF ${ }^{33}$ for possible band assignments.

The gemstone (fig. 17) shows the typical Raman bands of microcline $\left[\mathrm{K}\left(\mathrm{AlSi}_{3} \mathrm{O}_{8}\right)\right]$, a tectosilicate mineral belonging to the green amazonite stone. ${ }^{34}$

Conversely, the bead (fig. 18) shows the characteristic bands of the fluorapatite $\left[\mathrm{Ca}_{5}\left(\mathrm{PO}_{4}\right)_{3} \mathrm{~F}\right]$.

The employment of amazonite as a gemstone is mainly attested in Egypt, where amazonite and turquoise were used for manufacturing disc, barrel and teardrop shaped beads as early as in the Predynastic Period. ${ }^{35}$ Amazonite was one of the most used gemstones during the Dynastic Period, together with carnelian, amethyst, red jasper, lapis lazuli, and turquoise, and it was also one of the most frequently mentioned stones in Dynastic texts, where the Egyptian name of amazonite was nšmt (neshmet). ${ }^{36}$ Attestations in the Near East originate from Mesopotamia, where beads of amazonite had been found in the Royal Cemetery of $\mathrm{Ur}^{37}$ and amazonite was used for manufacturing beads and cylinder seals retrieved in Neo-Assyrian contexts. ${ }^{38}$

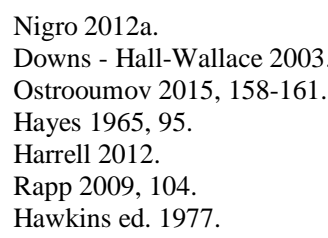




\section{THE CARNELIAN BEAD (KB.19.B.140)}

In the $15^{\text {th }}$ season (2019) in a destruction layer (F.978) excavated just outside Wall W.1187, the eastern limit of Eastern Pavilion, a barrel-shaped carnelian bead (KB.19.B.140) was found. The bead is $30.1 \mathrm{~mm}$ long and weighs $14.71 \mathrm{~g}$. The upper face diameter is $12.37 \mathrm{~mm}$, while the lower face diameter is $11.53 \mathrm{~mm}$. The maximum diameter at the mid-height of the bead is $17.08 \mathrm{~mm}$. In the centre of the top circular face there is a very small incision, where the piercing of the bead had been started, and then interrupted perhaps after that the gemstone was damaged on its side (fig. 19).

\subsection{Stone identification and interpretation}

The stone of the barrel-shaped bead has been identified through petrographic analyses, in particular with Raman spectrography and diffractometry carried out in the laboratories of the Department of Earth Sciences of Sapienza University. The analyses have shown that the bead is made of raw carnelian (orange chalcedony), before a careful firing treatment made it redder and more lustrous.

The barrel-shaped is a quite common bead type well known from the Royal Cemetery of Ur, ${ }^{39}$ and was widely spread over Mesopotamia, Syria and the Levant during the mid- $3^{\text {rd }}$ millennium BC..$^{40}$

\section{IMPORTS IN BATRAWY AND THEIR HISTORIC-ARCHAEOLOGICAL IMPLICATIONS}

The three finds from Entrance Hall L.1100, actually at any extent fallen down from the upper storey of the "Palace of the Copper Axes", and the carnelian bead from the Eastern Pavilion again testify to the network of international exchange with which the palace was connected.

The Egyptian green talc-schist palette, together with another fragmentary incised palette found in 2011 (KB.11.B.100), and with the bi-conical amethyst bead in the princess' necklace (KB.11.B.101) found in Hall L.1110, ${ }^{41}$ speaks for the inclusion of Batrawy among the centers trading with the Pharaonic Kingdom between the IV and the VI Dynasty (fig. 20). ${ }^{42}$ The connection with Egypt through the "Copper Route" is also suggested by the

39 Woolley 1934, pl. 134, U.8569.

40 Carnelian was really appreciated in Mesopotamia and it was second only to lapis lazuli for the production of beads and amulets (Moorey 1994, 97-98). It is attested in Syria, and at Ebla carnelian is also mentioned in administrative tables from the Royal Archives (Peyronel - Vacca 2013, 443-444). In Southern Levant barrelshaped carnelian beads have been found in EBA III contexts in Tomb F3 at Tell es-Sultan/Jericho (Kenyon 1960, 155-156, fig. 55), and at Tell ed-Duweir/Lachish (Tufnell 1958, pl. 29:6 and 21); different types of carnelian beads have been also found at Tell el-Mutesellim/Megiddo, Tell 'Arad, Bab edh-Dhra' (Nigro 2012a, fn. 9).

41 Nigro 2012a, 230-231, figs. 15-16; 2014a, 44, figs. 1, 8. The amethyst from the necklace should be extracted in Egypt in Wadi Abu Had, in the northern part of the Eastern Desert, a source used for amethyst mining as early as in the I Dynasty (Andrews 1991; Bomann - Young 1994; Astor - Harrell - Shaw 2000, 50-52). The other famous sources of amethyst were at Gebel el-Asr, in the Western Desert, and in the Eastern Desert at Wadi Abu Diyeiba (Harrell - Sidebotham 2004) and Wadi el-Hudi, $35 \mathrm{Km}$ south-east of Aswan, the use of which can be traced back to the Middle Kingdom (Fakhry 1952; Sadek 1980; Shaw - Jameson 1993).

42 Nigro 2014a, 49. 
building technique of the Main Inner City-Wall ${ }^{43}$ and by some pottery finds, as like as a "lotus vase" (KB.11.B.1128/76) made of the local fabric according with an Egyptian shape. ${ }^{44}$ Moreover, the incrustations identified on the palette, sampled and analyzed, turned out to be umber, a natural pigment mainly composed of red ochre and used as face-paint in Egypt. ${ }^{45}$ The association of red ochre with palette, often preserved as stains on the surface of these items, testify to their use for face makeup also in Batrawy. ${ }^{46}$ The discovery of this cosmetics once again shows how the members of the ruling class of a Southern Levantine city replicated Egyptian élite life-style to mark their rank. ${ }^{47}$ Makeup instruments were typically owned by the urban élite, even in a far away centre like Batrawy.

As regards the gemstones found during the $14^{\text {th }}-15^{\text {th }}$ seasons, they are made of three different semi-precious stones. The first one (KB.18.B.50) is made of amazonite. The sources of this somewhat rare semi-precious green-cyan stone were very far from Batrawy. Ores of amazonite active in pre-classical periods are known in the Eastern Desert of Egypt, where two amazonite quarries are located at Gebel Migif in Wadi Shait, not far from the Red Sea, and at Gebel Hafafit in Wadi Fayrouz. ${ }^{48}$ Other ancient sources are in the southeastern Libya's Eghei Mountains, ${ }^{49}$ Sudan, Ethiopia ${ }^{50}$ and in the southern Urals in Russia. ${ }^{51}$

We cannot say nothing more precisely about the provenance of the gem, unless by cutting a piece of it to undergo a more detailed analysis. The most natural carrier is again an Egyptian one, and the route is the same of copper and other precious stuff traded across the Sinai and along the Wadi 'Arabah. ${ }^{52}$ Conversely, if the Russian origin is hypothesized, we have to reconstruct a track across Caucasus, Armenia, Anatolia, and Syria which is also very suggestive as it might be similar to or even coincide with the one followed by the bear's skin found in Pillared Hall L.1040 along with the symbols of power, i.e. the copper axes (fig. 21). ${ }^{53}$

The second small bead (KB.18.B.63), apparently belonging to a lost necklace, is made of fluorapatite, a somewhat rare but not so precious cyan stone which is much easier to find in respect of other semi-precious stones in the majority of geological deposits of the Southern Levant.

The third precious barrel-shaped bead (KB.19.B.140) is made of carnelian and possibly was being produced at the site, as it was not yet pierced but showed the beginning of the

$43 \quad$ Nigro 2014a, fn. 70.

44 Nigro 2014a, 46, fig. 11; Sala 2014b, 60-70.

45 Following Petrie's interpretation, it was generally assumed that palettes played a central role in the preparation of cosmetics (Petrie et al. 1896, 10).

46 Lucas 1930, 44. Palettes show traces of different substances used as cosmetics, as well as galena, hematite, and obviously red ochre, which were processed on the palettes probably mixed with other animal or vegeta substances as fats, resins, and oils. The presence of these cosmetic products is attested both in funerary and settlement contexts (Baduel 2008, 1068)

47 Nigro et al. 2018, 120

48 Harrell 2012; Harrell - Osman 2007; Harrell - Storemyr 2009, 18

De Michele - Piacenza 1999

Ostrooumov 2015, 17, see also fig. 2.1.

Ostrooumov 2015, 14

Nigro 2014a, fig. 1.

Nigro 2014b, 265-266. 
hole, baked and polished. ${ }^{54}$ The known sources of carnelian are again the Eastern and Western Deserts of Egypt, ${ }^{55}$ Wadi 'Arabah, the southern Sinai, or the western mountainous region of Saudi Arabia, ${ }^{56}$ even though similar beads are also attested to in Mesopotamia, namely in the Royal Cemetery of Ur as stated above (fn. 39).

Both the amazonite and the carnelian beads were unfinished. Their shapes and surfaces examined on a microscope show that the process of cutting, polishing and piercing was interrupted by the fire which destroyed the city. This points to Batrawy not only as a centre importing gemstones - as the finding of the necklace from Hall L.1110 well demonstrated but also as a working station for semi-precious stones.

\section{REFERENCES}

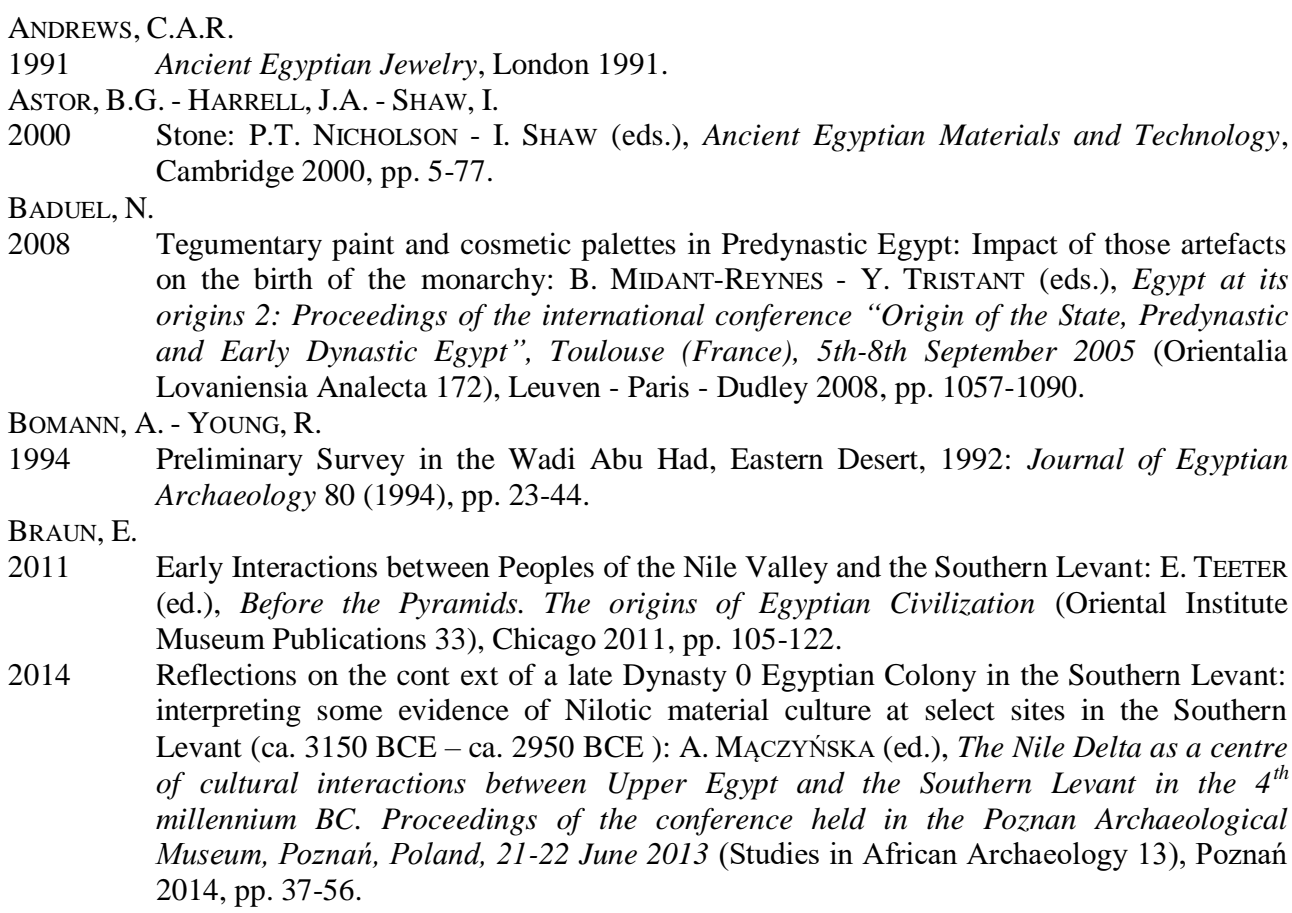
on the birth of the monarchy: B. MidAnT-ReYnES - Y. TRISTANT (eds.), Egypt at its origins 2: Proceedings of the international conference "Origin of the State, Predynastic and Early Dynastic Egypt", Toulouse (France), 5th-8th September 2005 (Orientalia Lovaniensia Analecta 172), Leuven - Paris - Dudley 2008, pp. 1057-1090.

1994 Preliminary Survey in the Wadi Abu Had, Eastern Desert, 1992: Journal of Egyptian Archaeology 80 (1994), pp. 23-44.

BRAUN, E.

2011 Early Interactions between Peoples of the Nile Valley and the Southern Levant: E. TEETER (ed.), Before the Pyramids. The origins of Egyptian Civilization (Oriental Institute Museum Publications 33), Chicago 2011, pp. 105-122.

2014 Reflections on the cont ext of a late Dynasty 0 Egyptian Colony in the Southern Levant: interpreting some evidence of Nilotic material culture at select sites in the Southern Levant (ca. 3150 BCE - ca. 2950 BCE ): A. MĄCZYŃSKA (ed.), The Nile Delta as a centre of cultural interactions between Upper Egypt and the Southern Levant in the $4^{\text {th }}$ millennium BC. Proceedings of the conference held in the Poznan Archaeological Museum, Poznań, Poland, 21-22 June 2013 (Studies in African Archaeology 13), Poznań 2014, pp. 37-56.

54 In addition to the carnelian beads belonging to the four-strings necklace, another spherical bead made of carnelian was found in the Eastern Pavilion of the "Palace of the Copper Axes" in 2006 season (Nigro ed 2008, 160, fig. 4.61,a).

55 Carnelian was found in pebbles in the Eastern Desert in the regions of Wadi Abu Gerida and Wadi Saga, and in the Western Desert near Gebel el-Asr (Sowada 2009, 236).

56 Sowada 2009, 94-95, 236; Nigro 2012a, 231, fig. 7; 2014a, 44. 
BRAUN, E. - VAN DEN BRINK, E.C.M.

2008 Appraising South Levantine-Egyptian interaction: recent discoveries from Israel and Egypt: B. Midant-ReYnes - Y. TRISTANT (eds.), Egypt at its Origins 2. Proceedings of the Third International Conference "Origin of the State. Pre-dynastic and Early Dynastic Egypt", Toulouse (France), 5th-8th September 2005 (Orientalia Lovaniensia Analecta 172), Leuven - Paris - Dudley 2008, pp. 643-680.

DOWNS, R.T. - HaLl-WALlaCe, M.

2003 The American Mineralogist Crystal Structure Database: American Mineralogist 88 (2003), pp. 247-250.

FAKHRY, A.

1952 The inscriptions of the amethyst mines at Wadi El-Hudi, Cairo 1952.

Geraty, L.T. - HerR, L.G. - LABIANCA, Ø.S. - BATTENFIELD, J.R. - Boling, R.G. - ClaRK, D.R. LAWLOR, J.I. - MITCHEL, L.A. - YOUNKER, R.W.

1986 Madaba Plains Project: A preliminary Report of the 1984 Season at Tell el-'Umeiri and Vicinity: Bulletin of the American Schools of Oriental Research, Supplementum 24 (1986), pp. 117-144.

Gražulis, S. - Chateigner, D. - Downs, R.T. - Yokochi, A.F.T. - Quirós, M. - LutTerotti, L. Manakova, E. - ButKus, J - Moeck, P. - Le Bail, A.

2009 Crystallography Open Database - an open-access collection of crystal structures: Journal of Applied Crystallography 42 (2009), pp. 726-729.

GREENBERG, R. - EISENBERG, E.

2002 Egypt, Bet Yerah and Early Canaanite Urbanization: E.C.M. van DEN BRINK - T.E. LEVY (eds.), Egypt and the Levant. Interrelations from the 4th through the Early 3rd Millennium B.C.E., London - New York 2002, pp. 213-222.

GREenBERG, R. - PAZ, S. - WENGROW, D. - ISERLIS, M.

2012 Tel Beth Yerah: Hub of the Early Bronze Age Levant: Near Eastern Archaeology 75 (2012), pp. 88-107.

HARRELL, J.A.

2012 Gemstones: W. WENDRICH (ed.), UCLA Encyclopedia of Egyptology, Los Angeles 2012 http://digital2.library.ucla.edu/viewItem.do?ark=21198/zz002czx 1r.

HARRELL, J.A. - OSMAN, A.

2007 Ancient amazonite quarries in the Eastern Desert: Egyptian Archaeology 30 (2007), pp. 26-28.

HARRELl, J.A. - Sidebotham, S.

2004 Wadi Abu Diyeiba: An amethyst mine in Egypt's Eastern Desert: Minerva 15/6 (2004), pp. 12-14.

HARRELL, J.A. - STOREMYR, P.

2009 Ancient Egyptian quarries: an illustrated overview: N. ABU-JABER - E. BloXAM - P. DEGRYSE - T. HELDAL (eds.), QuarryScapes: Ancient stone quarry landscapes in the Eastern Mediterranean (Geological Survey of Norway Special Publication 12), Trondheim 2009, pp. 7-50.

HAWKINS, J.D. (ed.)

1977 Trade in the ancient Near East. Papers presented to the XXIII Rencontre Assyriologique HAYES, W.C. Internationale, University of Brimingham, 5-9 July, 1976, London 1977.

1965 Most Ancient Egypt, Chicago 1965.

HÖFLMAYER, F.

2014 Dating catastrophes and collapses in the ancient Near East: the end of the first urbanization in the Southern Levant and the $4.2 \mathrm{ka} \mathrm{BP}$ event: L. Nigro (ed.), Overcoming 
Catastrophes. Essays on disastrous agents characterization and resilience strategies in pre-classical Southern Levant (Rome «La Sapienza» Studies on the Archaeology of HÜBNER, U. Palestine and Transjordan 11), Rome 2014, pp. 117-140.

2011 Die Archäologische Expedition 2011 in die Region um Petra: Ausgrabungen auf Umm Saysabān: Natur und Mensch. Jahresmitteilungen der Naturhistorische Gesellschaft Nuernberg 2011, pp. 157-168.

JACOBS, P.F.

1996 A cosmetic palette from Early Bronze Age III at Tell Halif: J.D. SEGER (ed.), Retrieving the past: essays on archaeological research and methodology in honor of Gus W. van Beek, Winona Lake 1996, pp. 123-134

JACOBS, P.F. - SEGER, J.D.

2017 Lahav VI: Excavations in Field I at Tell Halif, 1976-1999. The Early Bronze III to Late Arabic Strata, Winona Lake 2017.

KENYON, K.M.

1960 Excavations at Jericho. Volume One. The Tombs excavated in 1952-1954, London 1960.

KLEMM, R. - KLEMM D.D.

2008 Stones and Quarries in Ancient Egypt, London 2008.

2003 Worked Stones: W.E. RAST - R.T. Schaub, Bâb edh-Dhrâ': Excavations at the Town Site (1975-1981). Part 1: Text, Part 2: Plates and Appendices (Reports of the Expedition to the Dead Sea Plain, Jordan, Volume II), Winona Lake 2003, pp. 622-637.

LUCAS, A.

1930 Cosmetics, Perfumes and Incense in Ancient Egypt: Journal of Egyptian Archaeology 16/1-2 (1930), pp. 41-53.

MEDEGHINI, L. - NigRo, L.

2017 Khirbet al-Batrawy ceramics: a systematic mineralogical and petrographic study for investigating the material culture: Periodico di Mineralogia 86 (2017), pp. 19-35.

Medeghini, L. - Fabrizi, L. - De Vito, C. - Mignardi, S. - Nigro, L. - Gallo, E. - Fiaccavento, C.

2016 The ceramic of the "Palace of the Copper Axes" (Khirbet al-Batrawy, Jordan): A palatial special production: Ceramic International 42/5 (2016), pp. 5952-5962.

DE Michele, V. - PiACENZA, B.

1999 L'amazzonite di Eghei Zuma (Tibesti sett., Libia): Sahara 11 (1999), pp. 109-112.

DE MiRosCHEDJi, P.

2002 The socio-political dynamics of Egyptian-Canaanite interaction in the Early Bronze Age: E.C.M. VAN DEN BRINK - T.E. LEVY (eds.), Egypt and the Levant. Interrelations from the 4th through the Early 3rd Millennium B.C.E., London - New York 2002, pp. 39-57.

De Miroschedi, P. - SAdeK, M. - Faltings, D. - Boulez, V. - NAggiar-Moliner, L. - Sykes, N. TENBERG, $\mathrm{M}$.

2001 Les fouilles de Tell es-Sakan (Gaza): nouvelles données sur les contacts égyptoMoorey, P.R.S. cananéens aux IVe-IIIe millénaires: Paléorient 27/2 (2001), pp. 75-104.

1994 Ancient Mesopotamian Materials and Industries. The Archaeological Evidence, Oxford 1994.

NigRO, L.

2010a In the Palace of the Copper Axes/Nel Palazzo delle Asce di Rame. Khirbet al-Batrawy: the discovery of a forgotten city of the III millennium BC in Jordan/Khirbet al-Batrawy: la scoperta di una città dimenticata del III millennio a.C. in Giordania (Rome «La Sapienza» Studies on the Archaeology of Palestine \& Transjordan, Colour Monographs I), Rome 2010. 
2010b Quattro asce di rame dal Palazzo B di Khirbet al-Batrawy (Bronzo Antico IIIB, 25002300 a.C.): Scienze dell'Antichità 16 (2010), pp. 561-572.

2010c Khirbet al-Batrawy: a third millennium city in Jordan: American Journal of Archaeology 114 (2010), pp. 514-516.

2010d Between the Desert and the Jordan: Early Urbanization in the Upper Wadi az-Zarqa - the EB II-III fortified town of Khirbet al-Batrawy: P. MatTHAIE - F. PINNOCK - L. Nigro - N. MArchetti (eds.), 6 ICAANE. Proceedings of the $6^{\text {th }}$ International Congress of the Archaeology of the Ancient Near East. 5 May - 10 May 2008, "Sapienza”, Università di Roma, Volume 2, Wiesbaden 2010, pp. 431-458.

2011 Dominating the River: Khirbet al-Batrawy, an EB II-III City in North-Central Jordan: Syria 88 (2011), pp. 59-74.

2012a An EB IIIB (2500-2300 BC) gemstones necklace from the Palace of the Copper Axes at Khirbet al-Batrawy, Jordan: Vicino Oriente XVI (2012), pp. 227-243.

2012b Khirbet al-Batrawy: American Journal of Archaeology 116/4 (2012), pp. 705-706.

2012C Khirbet al-Batrawy: Rise, Flourish and Collapse of an Early Bronze Age City in Jordan: R. Matthews - J. Curtis (eds.), Proceedings of the 7th International Congress on the Archaeology of the Ancient Near East. 12 April - 16 April 2010, the British Museum and UCL, London, Volume 1, Wiesbaden 2012, pp. 609-628.

2013a Urban Origins in the Upper Wadi az-Zarqa' Jordan: The City of Khirbat al-Batrawi in the third Millennium BC: F. AL-HMOUD (ed.), Studies in the History and Archaeology of Jordan XI, Amman 2013, pp. 489-506.

2013b Khirbet al-Batrawy: An Early Bronze Age City at the fringes of the desert: Syria 90 (2013), pp. 189- 209.

2014a The Copper Routes and the Egyptian Connection in $3^{\text {rd }}$ millennium BC Jordan seen from the caravan city of Khirbet al-Batrawy: Vicino Oriente XVIII (2014), pp. 39-64.

2014b The King's Cup and the Bear Skin. Royal Ostentation in the Early Bronze III "Palace of the Copper Axes" at Khirbet al-Batrawy: Z. KAFAFI - M. MARAQTEN (eds.), A Pioneer of Arabia. Studies in the Archaeology and Epigraphyof the Levant and the Arabian Peninsulain Honor of Moawiyah Ibrahim (Rome «La Sapienza» Studies on The Archaeology of Palestine And Transjordan 10), Rome 2014, pp. 261-270.

2014c Khirbat al-Batrawy: G.J. CorbetT - D.R. Keller - B.A. PorTer - Ch.A. TutTle (eds.), Archaeology in Jordan, 2012 and 2013 Seasons (American Journal of Archaeology 118), Boston 2014, pp. 644-645.

2015 The Copper Axes Hoard in the Early Bronze IIIb Palace of Batrawy, Jordan: K RosińSKA-BALIK - A. OCHAl-CZARNOWICZ - M. CZARNowiCZ - J. DęBOwSKA-LudwiN (eds.), Copper and Trade in the South-Eastern Mediterranean Trade routes of the Near East in Antiquity (British Archaeological Reports International Series 2753), Oxford 2015, pp. 77-83.

2016 Khirbat al-Batrawi 2010-2013: The City Defenses and the Palace of Copper Axes: Studies on the History and Archaeology of Jordan XII: Transparent Borders (2016), pp. 135-154.

2017 The end of the Early Bronze Age in the Southern Levant. Urban Crisis and Collapse seen from two $3^{\text {rd }}$ Millennium BC-Cities: Tell es-Sultan/Jericho and Khirbet al-Batrawy: T. Cunninghm - J. Driessen (eds.), Crisis to Collapse. The Archaeology of Social Breakdown (AEGIS 11), Louvain 2017, pp. 149-172.

NigRo, L. (ed.)

2008 Khirbet al-Batrawy II. The EB II city-gate, the EB II-III fortifications, the EB II-III temple. Preliminary report of the second (2006) and third (2007) seasons of excavations (Rome «La Sapienza» Studies on the Archaeology of Palestine \& Transjordan 6), Rome 2008. 
2012 Khirbet al-Batrawy III. The EB II-III triple fortification line and the EB IIIB quarter inside the city-wall. Preliminary report of the fourth (2008) and fifth (2009) seasons of excavations (Rome «La Sapienza» Studies on the Archaeology of Palestine \& Transjordan 8), Rome 2012.

Nigro, L. - Montanari, D. - MuRA, F. - Yasine, J. - Rinaldi, T.

2018 A hoard of Nilotic nacreous shells from Egypt to Jericho (Early Bronze II, 3000-2800 BC): Their finding, content and historical archaeological implications": Palestine Exploration Quarterly 150/2 (2018), pp. 110-125.

NigRo, L. - SALA, M.

2010 Preliminary Report on the Fifth Season (2009) of Excavations at Khirbat al-Batrāwi (Upper Wādī az-Zarqā'), by the University of Rome "La Sapienza": Annual of the Department of Antiquities of Jordan 54 (2010), pp. 237-253.

2011 Preliminary Report on the Sixth (2010) Season of Excavation by "La Sapienza" University of Rome at Khirbat al-Batrāwī (Upper Wādī az-Zarqā'): Annual of the Department of Antiquities of Jordan 55 (2011), pp. 85-100.

2012 Preliminary Report of the Seventh Season (2011) of Excavations by the University of Rome "La Sapienza" at Khirbat al-Batrāwī (Upper Wādī az-Zarqā'): Annual of the Department of Antiquities of Jordan 56 (2012), pp. 45-54.

2013 Preliminary Report of the Eighth Season (2012) of Excavations by the University of Rome "La Sapienza" at Khirbat al-Batrawi (Upper Wadi az-Zarqa): HAWLIYYAT DA'IRAT AL-ATAR AL- 'AMMAT 57 (2013), pp. 217-228.

\section{OSTROOUMOV, M.N.}

2015 Amazonite: Mineralogy, Crystal Chemistry, and Typomorphism, Amsterdam 2015.

PETRIE, W.M.F.

1953 Ceremonial slate palettes (British School of Egyptian Archaeology Publications 66), London 1953.

1974 Prehistoric Egypt. Corpus of Prehistoric Pottery and Palettes, London 1974.

Petrie, W.M.F. - Quibell, J.E. - SPURRELl, F.

1896 Naqada and Ballas: 1895 (Egyptian Research Account Memoir 1), London 1896.

Peyronel, L. - VacCA, A.

2013 Natural Resources, Technology and Manufacture Processes at Ebla. A Preliminary Assessment: P. Matthiae - N. MarchetTi (eds.), Ebla and Its Landscape. Early State Formation in the Ancient Near East, Walnut Creek 2013, 431-449.

RAPP, G.

$2009 \quad$ Archaeomineralogy, Berlin $2009^{2}$.

RAST, W.E. - SCHAUB, R.T.

1989 Bâb edh-Dhrâ': Excavations in the Cemetery directed by Paul W. Lapp (1965-67) (Reports of the Expedition to the Dead Sea Plain, Jordan, Volume I), Winona Lake 1989.

2003 Bâb edh-Dhrâ': Excavations at the Town Site (1975-1981). Part 1: Text, Part 2: Plates and Appendices (Reports of the Expedition to the Dead Sea Plain, Jordan, Volume II), Winona Lake 2003.

SADEK, A.I.

1980 The Amethyst Mining Inscriptions of Wadi el-Hudi, Warminster 1980.

SALA, M.

2012 Egyptian and Egyptianizing objects from EB I-III Tell es-Sultan/ancient Jericho: Vicino Oriente XVI (2012), pp. 275-302.

2014a Stratigraphy, Pottery and Chronology at Khirbet el-Batrawy in the Framework of $3^{\text {rd }}$ Millennium BC Palestine and Transjordan: F. HöFlMAYER - R. EICHMAnN (eds.), Egypt 
and the Southern Levant in the Early Bronze Age (Orient-Archäologie 31), Leidorf 2014, pp. 259-292.

2014b EB II-III Aegyptiaca east of the Jordan: a reevaluation of trade and cultural interactions between Egypt and the Transjordanian urban centres: Vicino Oriente XVIII (2014), pp. 65-81.

SHAW, I. - JAMESON, R.

1993 Amethyst Mining in the Eastern Desert: A Preliminary Survey at Wadi el-hudi: The Journal of Egyptian Archaeology 79 (1993), pp. 81-97.

SOWADA, K.N.

2000 Egyptian Palettes in the EB II and EB III Canaan: P. Matthiae - A. EnEA - L. PeYronel F. PINNOCK (eds.), Proceedings of the First International Congress on the Archaeology of the Ancient Near East, Rome, May $18^{\text {th }}-23^{\text {rd }}$ 1998, Roma 2000, pp. 1527-1540.

2009 Egypt in the Eastern Mediterranean during the Old Kingdom. An Archaeological Perspective (Orbis Biblicus et Orientalis 237), Fribourg 2009.

STEVENSON, A.

2007 The material significance of Pre-dynastic and Early Dynastic palettes: R. MAIRS - A SteVenson (eds.), Current Research in Egyptology 2005. Proceedings of the Sixth Annual Symposium, University of Cambridge 2005, Oxford 2007, pp. 148-162.

2009 Palettes: W. Wendrich (ed.), UCLA Encyclopedia of Egyptology, Los Angeles 2009. http://digital2.library.ucla.edu/viewItem.do?ark=21198/zz001nf6c0.

2011 Material culture of the Predynastic Period: E. TEETER (ed.), Before the Pyramids. The origins of Egyptian Civilization (Oriental Institute Museum Publications 33), Chicago 2011, pp. 65-74.

TUFNELL, O.

1958 Lachish IV, The Bronze Age (The Wellcome-Marston Archaeological Research Expedition to the Near East, Vol. IV), London 1958.

WILKINSON, A.

1989 Objects from the Early Bronze II and III Tombs: W.E. RAST - R.T. SCHAUB, Bâb edhDhrâ': Excavations in the Cemetery directed by Paul W. Lapp (1965-67) (Reports of the Expedition to the Dead Sea Plain, Jordan, Volume I), Winona Lake 1989, pp. 444-470.

WOOLLEY, C.L.

1934 Ur Excavations II. The Royal Cemetery. A report on the Predynastic and Sargonid graves excavated between 1926 and 1931, London 1934. 


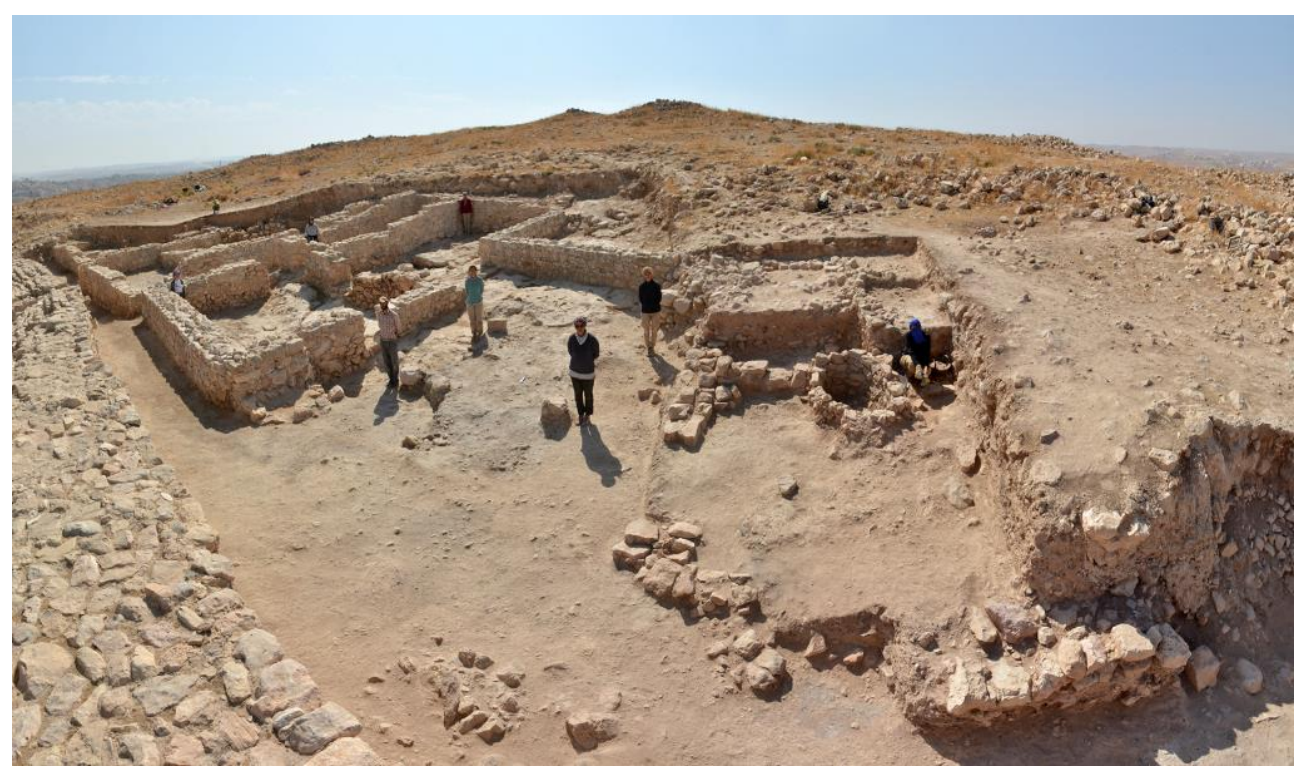

Fig. 1 - View of the "Palace of the Copper Axes" at the end of the $15^{\text {th }}$ season (2019) of excavations, with Entrance Hall L.1100 and Western Wing in the foreground; from northwest.

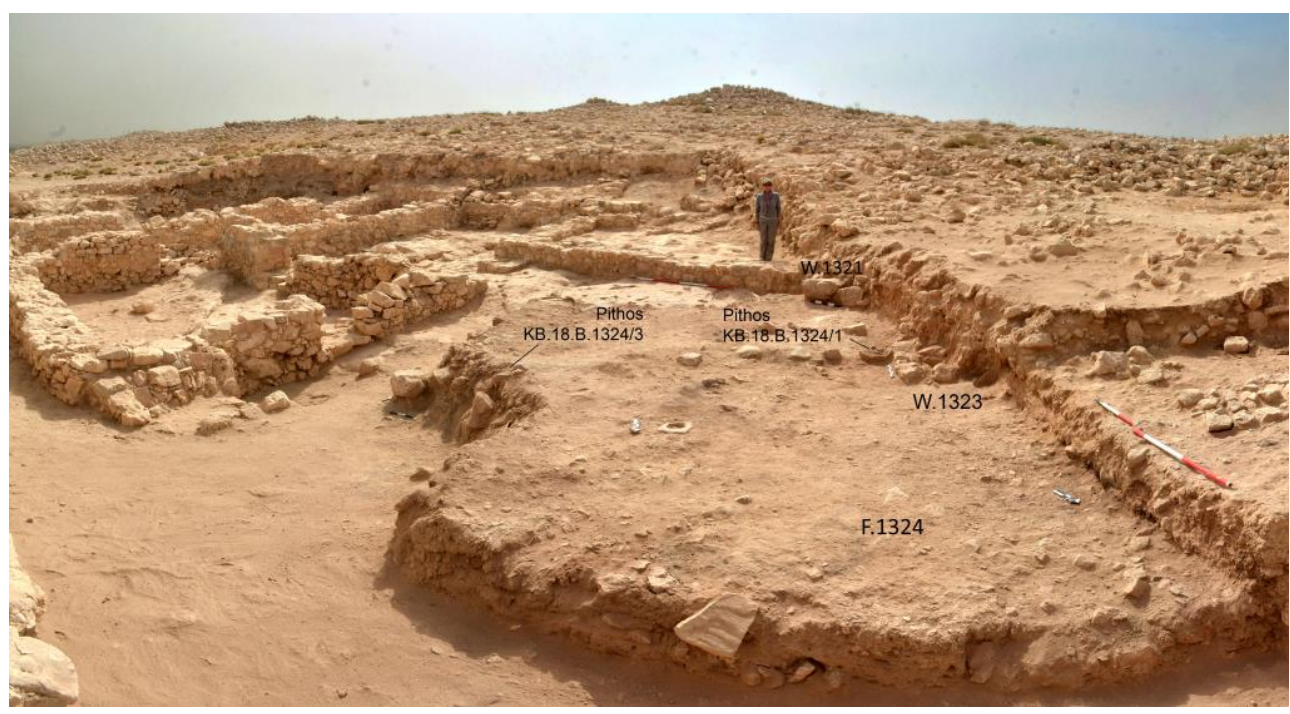

Fig. 2 - The upper destruction layer (F.1324) with pithos KB.18.B.1324/1 visible against Wall W.1323 and pithos KB.18.B.1324/3 close to pillar base B.1285; from north. 


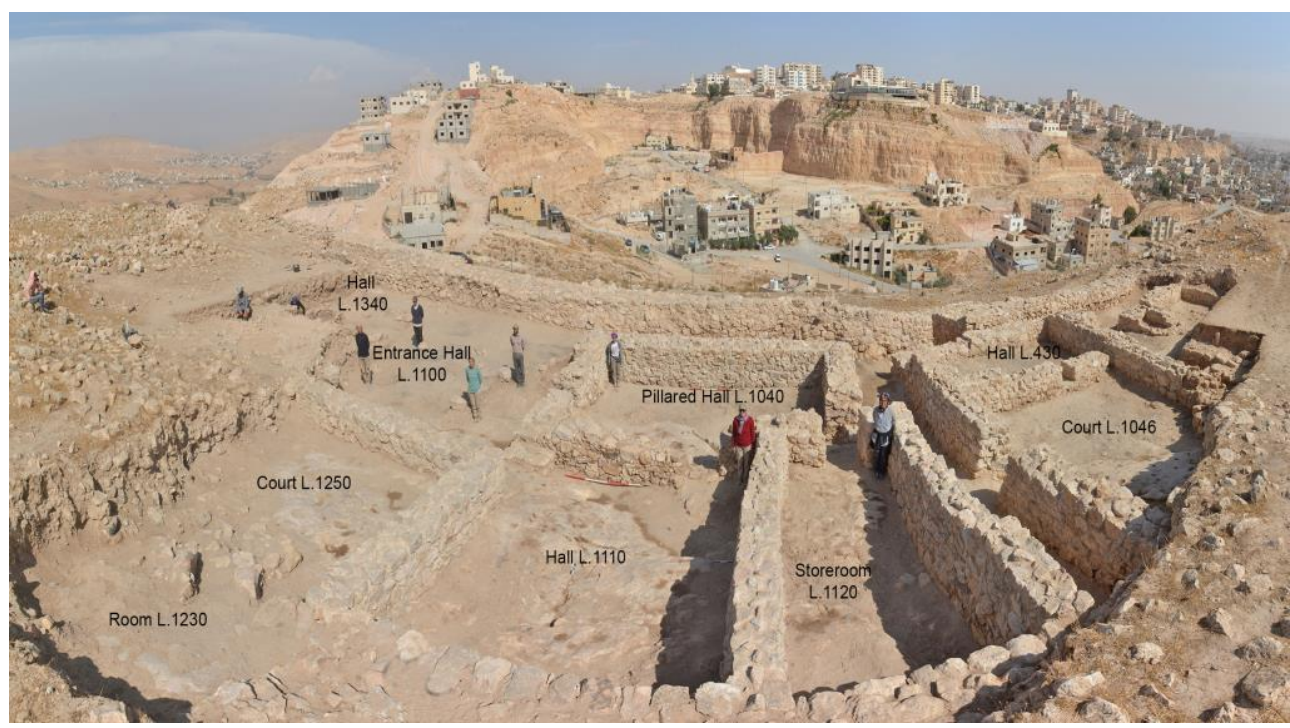

Fig. 3 - General view of the "Palace of the Copper Axes" at the end of the 2019 season of excavations and restorations; from south.

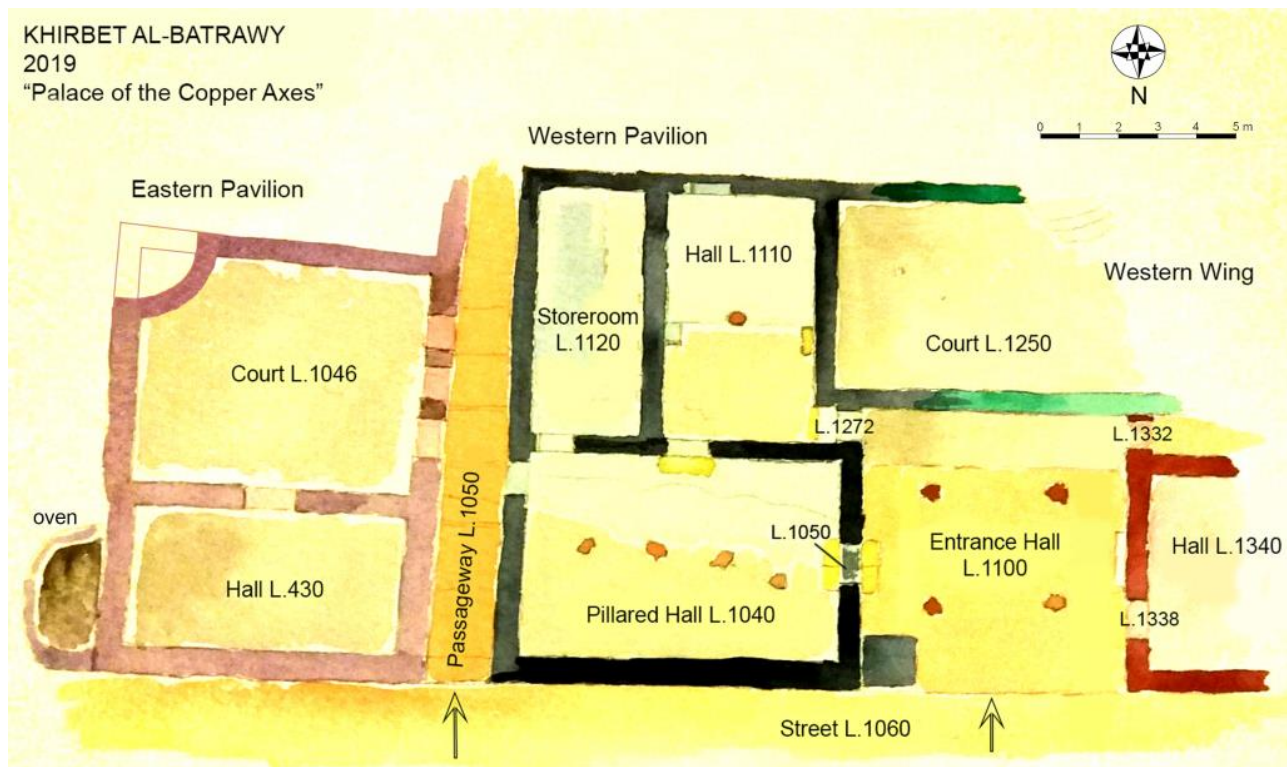

Fig. 4 - Reconstructive drawing of the "Palace of the Copper Axes" with the Entrance Hall in the middle of two symmetrical wings. 


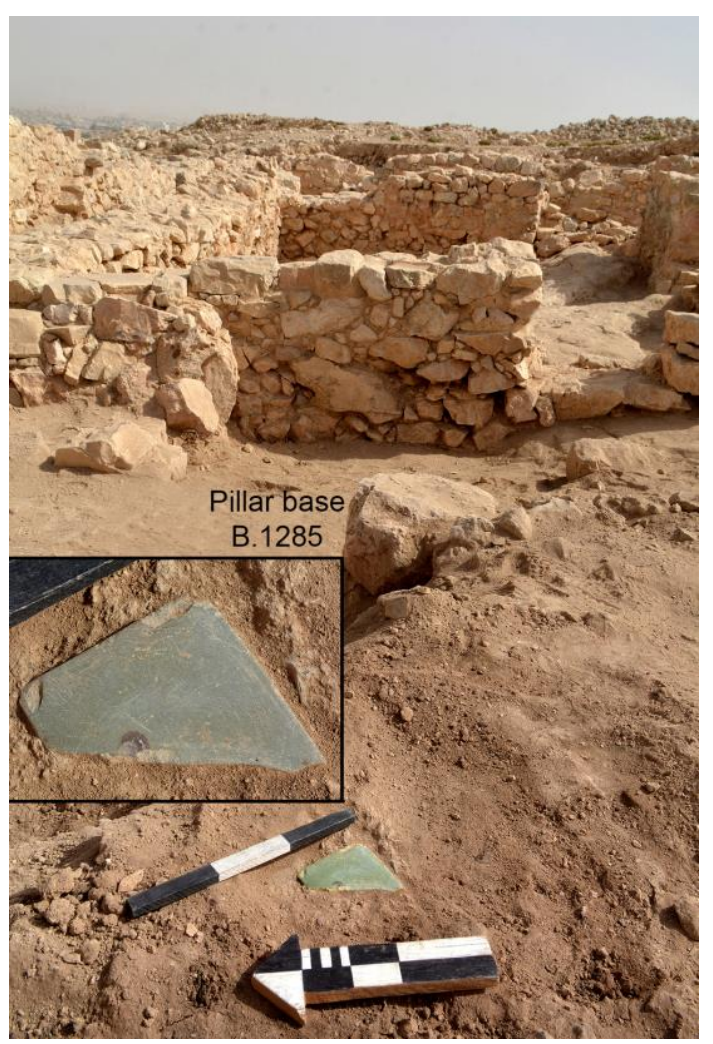

Fig. 5 - Palette KB.18.B.30 at the moment of its retrieval not far from pillar base B.1285; from west.

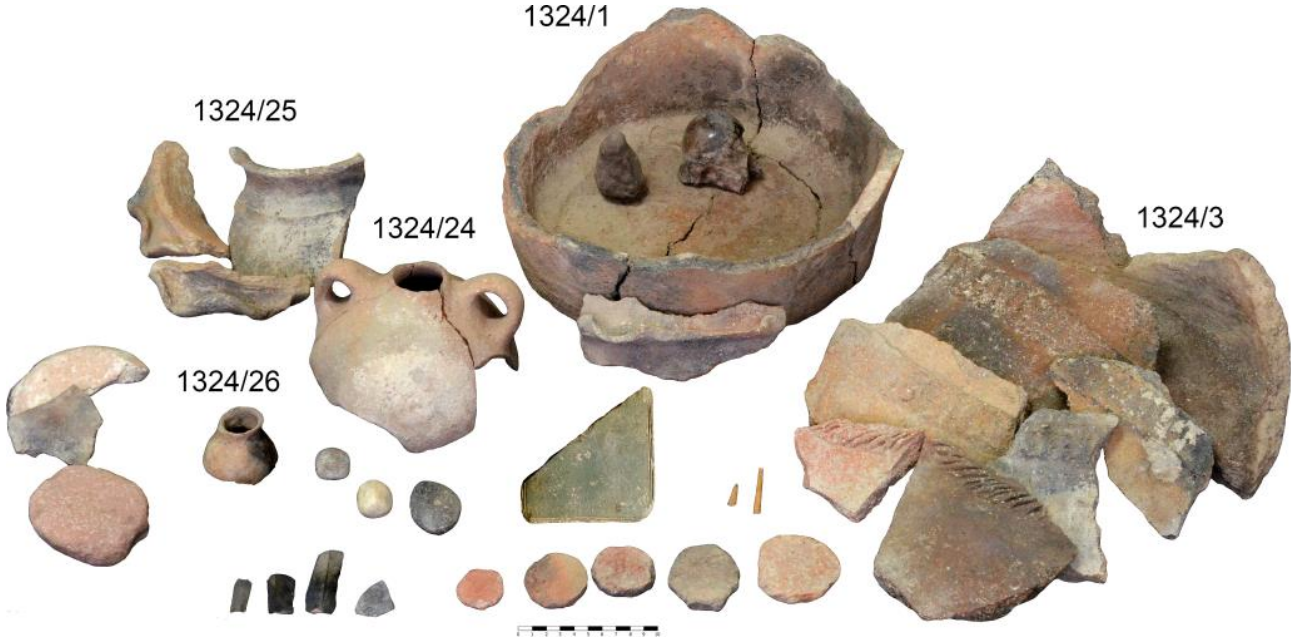

Fig. 6 - Ceramic vessels and items from destruction layer F.1324, with the green schist palette KB.18.B.30. 


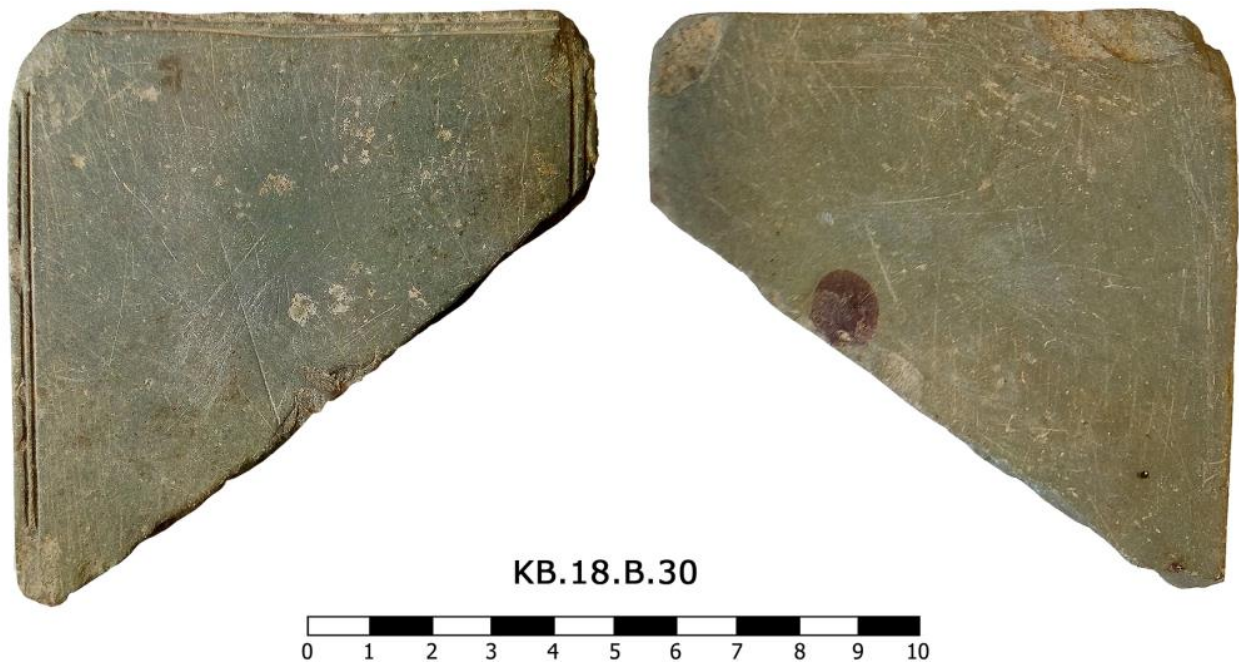

Fig. 7 - Palette KB.18.B.30 (on the left the front side, the reverse on the right).

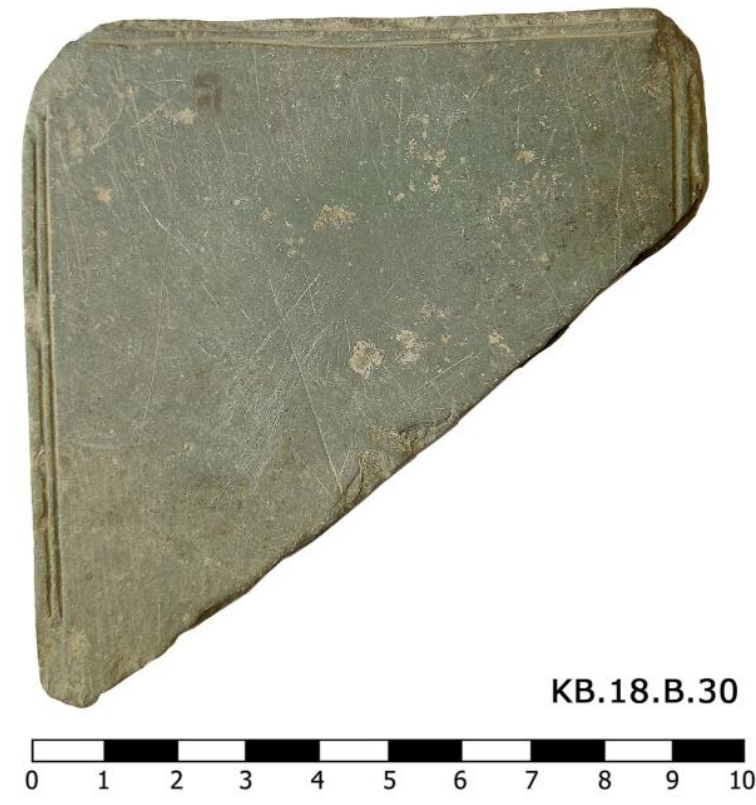

Fig. 8 - Detailed views of palette KB.18.B.30 and the engraving decoration.

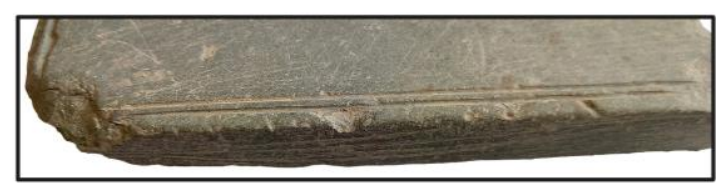




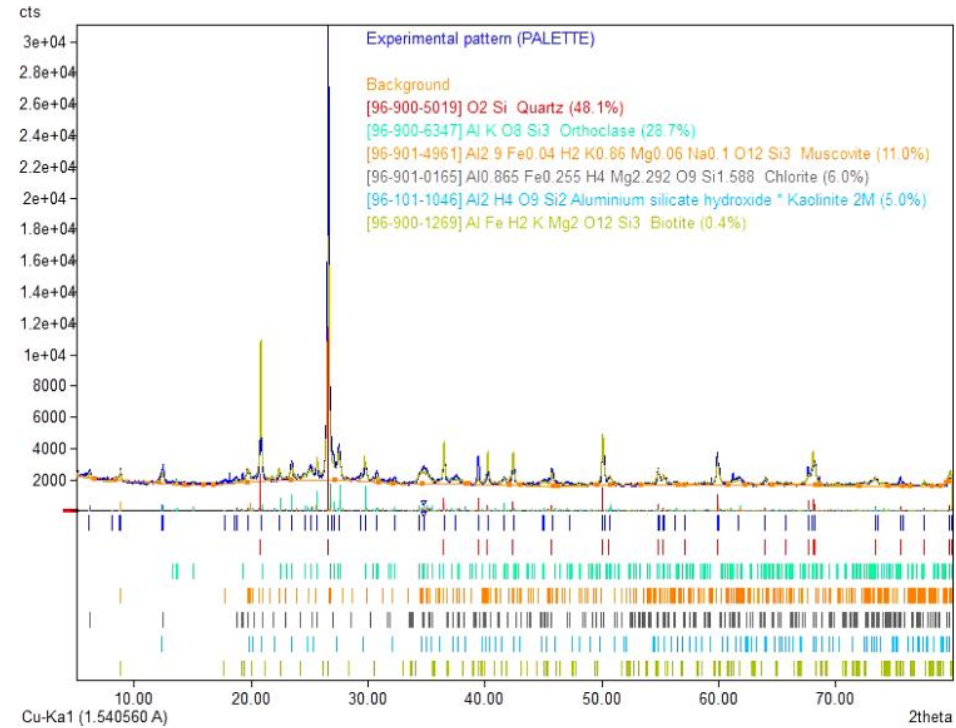

Fig. 9 - X-ray diffraction (XRD) pattern from palette KB.18.B.30 revealing the mineral composition of green talc-schist (Sapienza - CNIS).
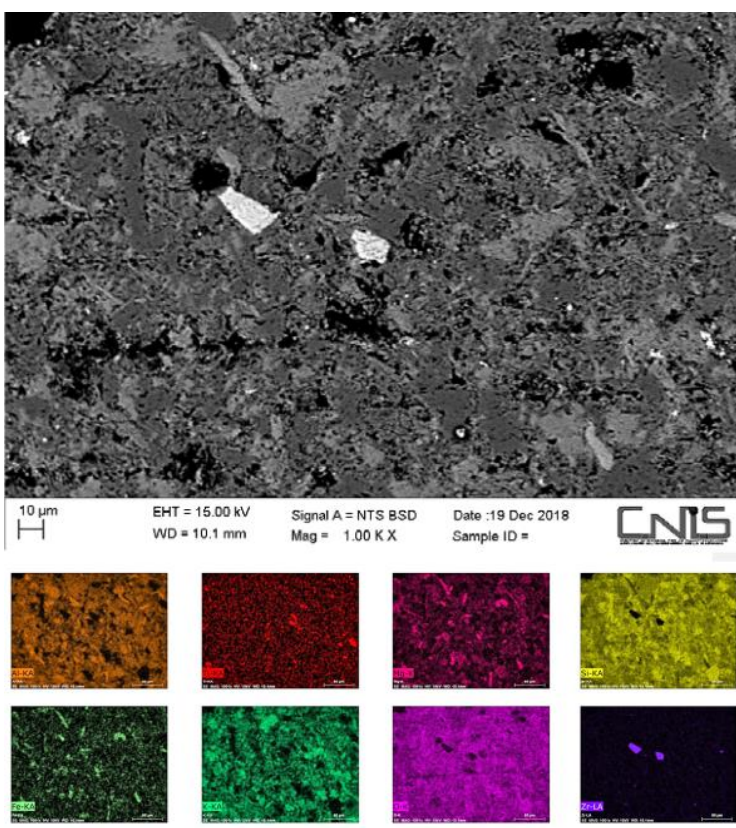

Fig. 10 - FESEM image of an area taken from the cross section of the palette and EDX map of the same area confirming the results obtained by the X-ray diffraction (Sapienza CNIS). 


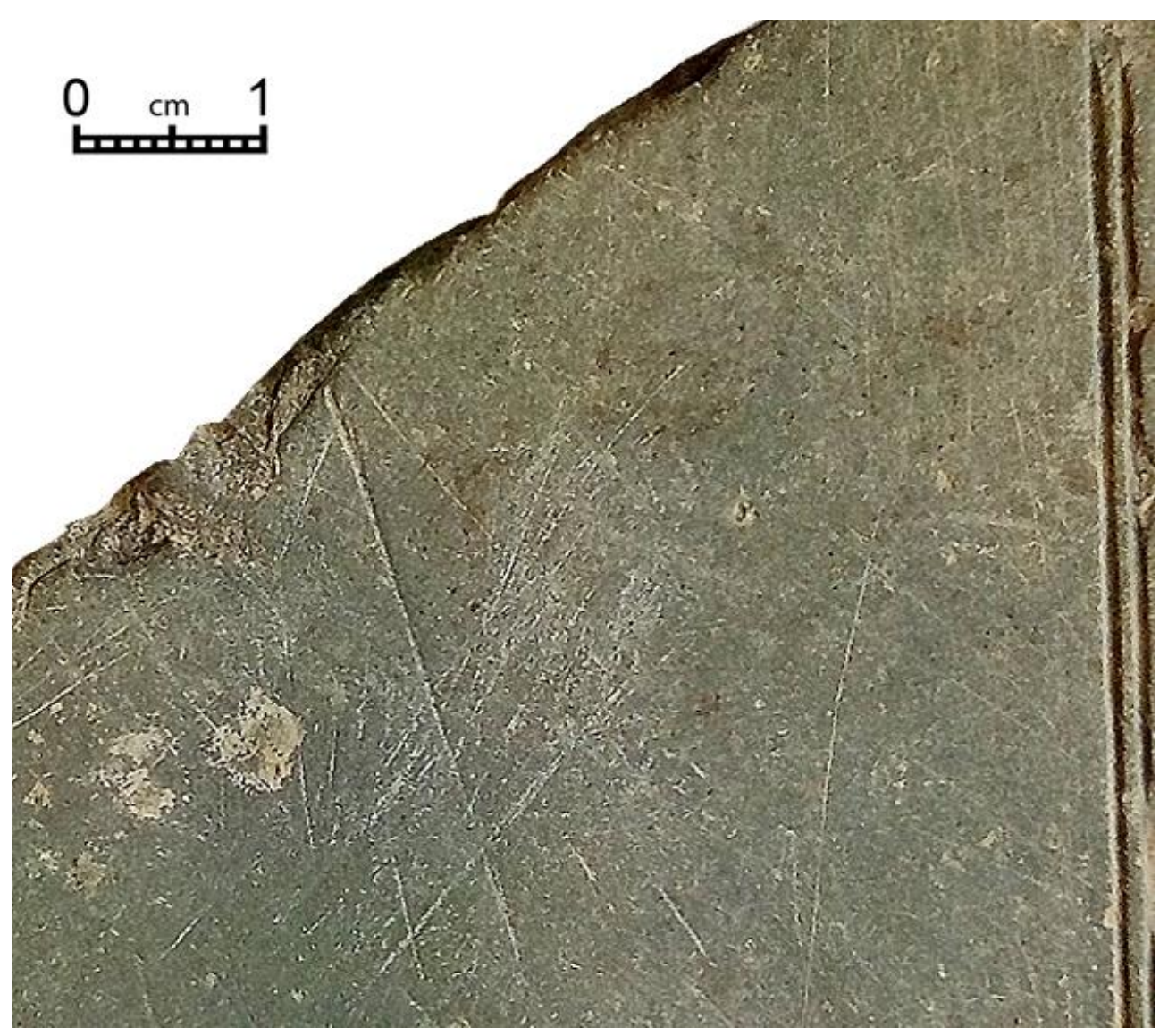

Fig. 11 - Scratches and traces of use clearly visible on the surface of palette KB.18.B.30.
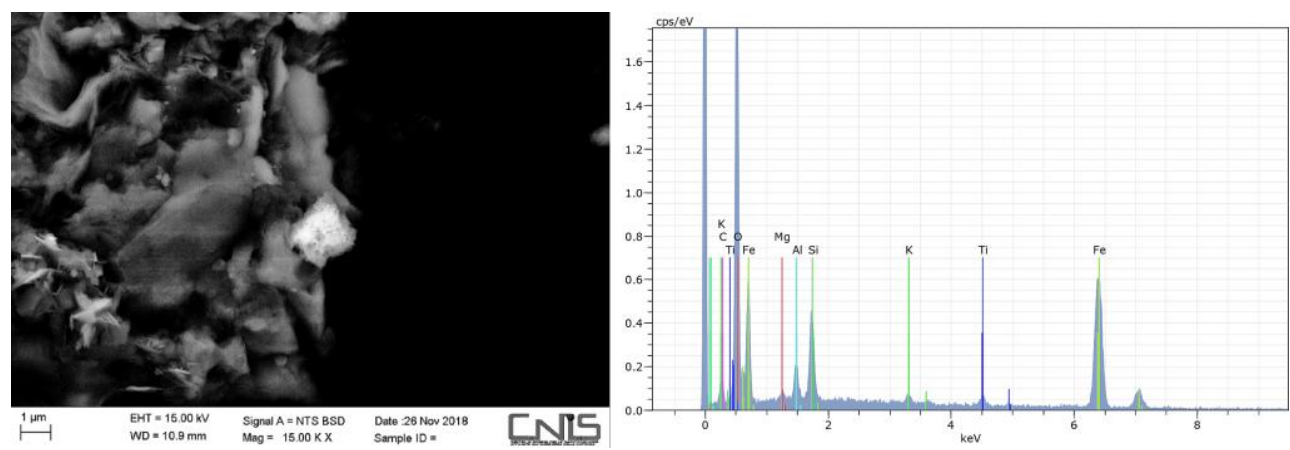

Fig. 12 - FESEM image of one of the red ochre grains visible on palette KB.18.B.30, and related EDX spectrum (Sapienza - CNIS). 

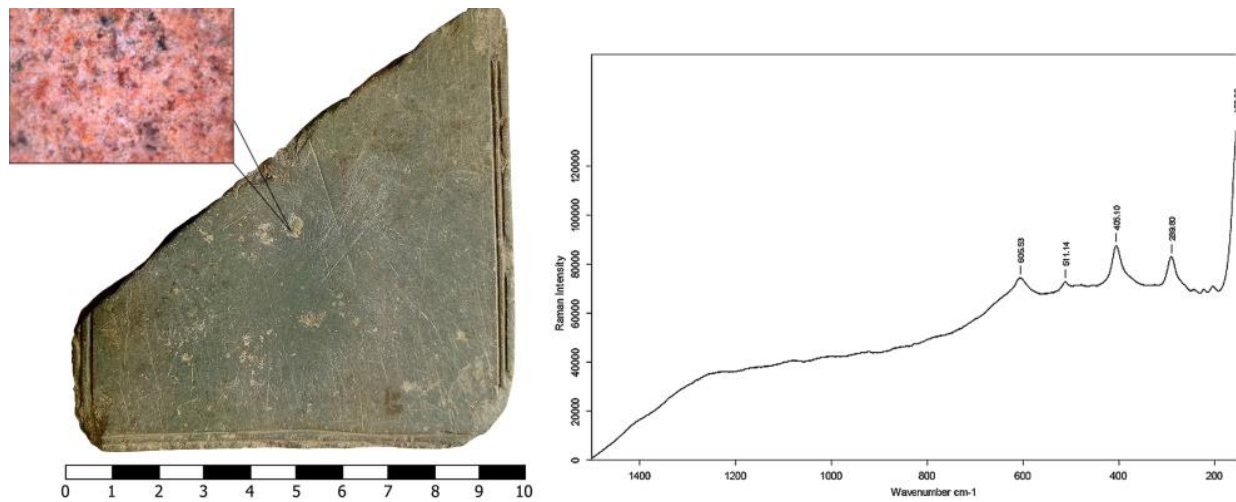

Fig. 13 - Red ochre from palette KB.18.B.30 and Raman spectrum obtained (Sapienza CNIS).

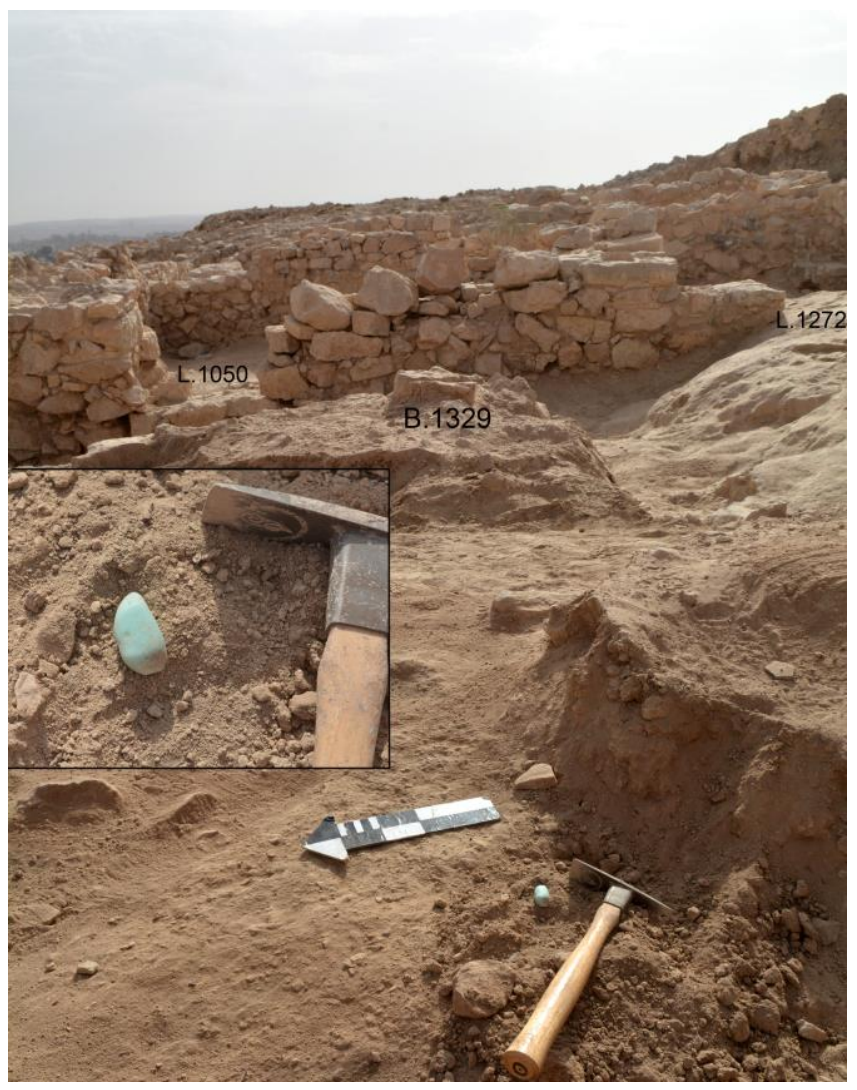

Fig. 14 - Amazonite gemstone KB.18.B.50 at the moment of its retrieval in the southwestern corner of Entrance Hall L.1100; from north-west. 
Fig. 15 - The greencyan amazonite gemstone KB.18.B.50.
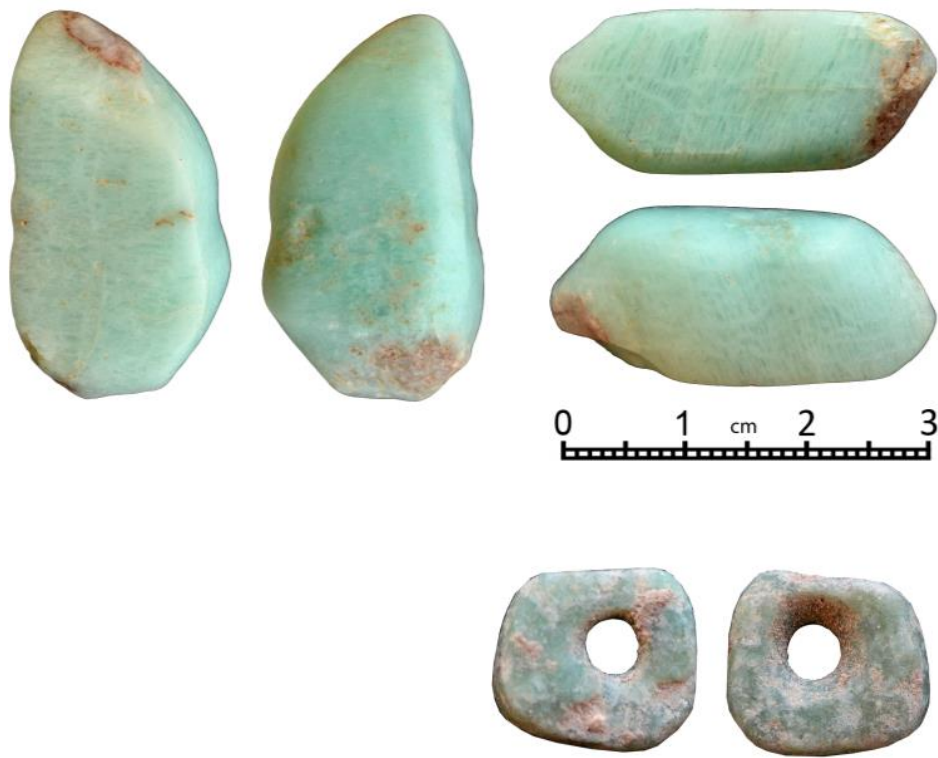

0

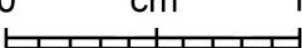

Fig. 16 - Bead KB.18.B.63, possibly part of a necklace.

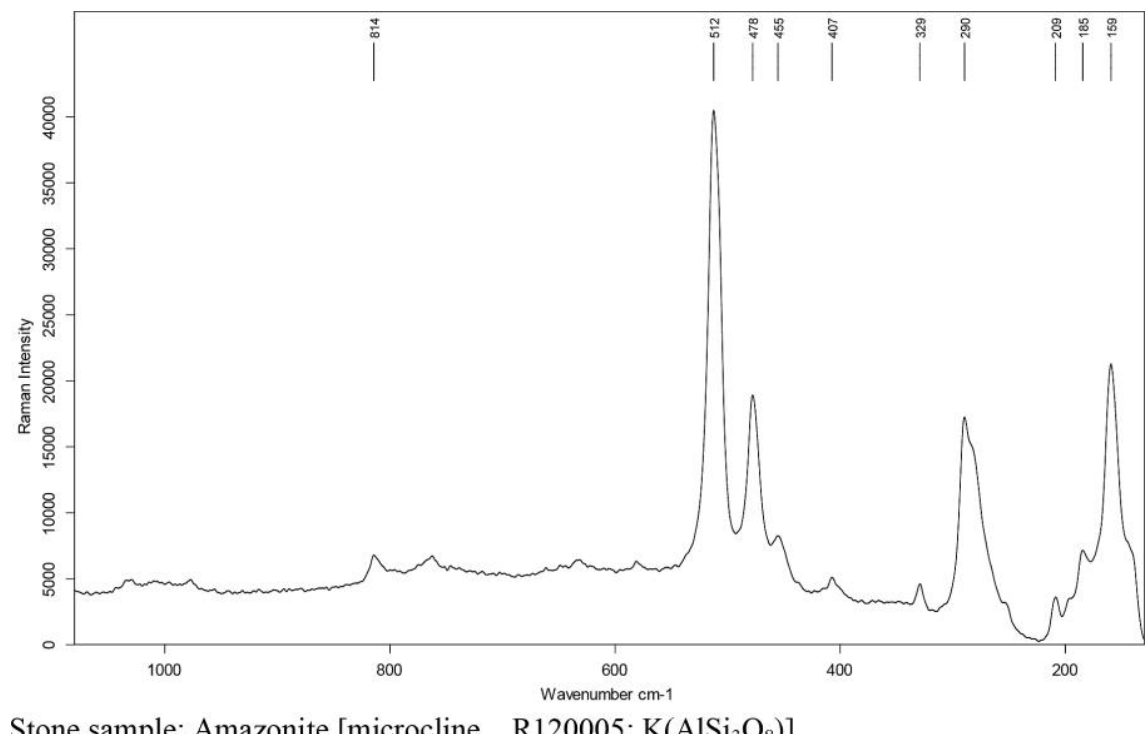

Stone sample: Amazonite [microcline_R120005: $\mathrm{K}\left(\mathrm{AlSi}_{3} \mathrm{O}_{8}\right)$ ]

Fig. 17 - Raman spectrum of gemstone KB.18.B.50 showing the typical Raman bands of microcline $\left[\mathrm{K}\left(\mathrm{AlSi}_{3} \mathrm{O}_{8}\right)\right]$, a tectosilicate mineral belonging to the green amazonite stone (Sapienza - CNIS). 


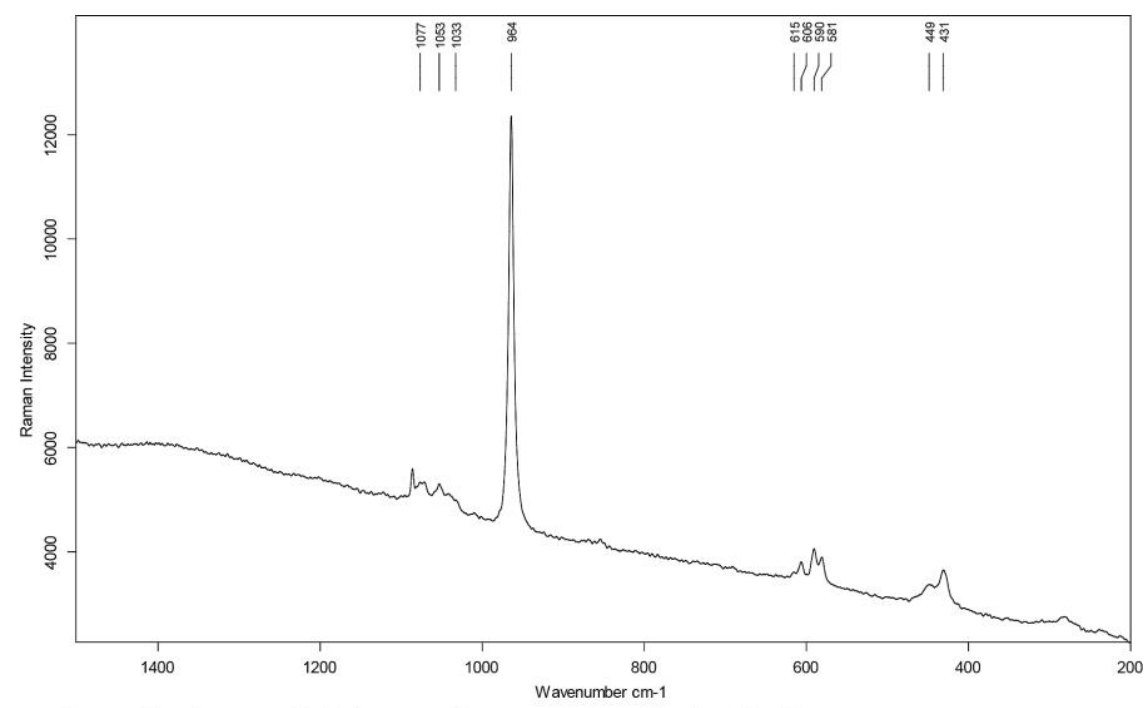

Bead sample: fluorapatite[Fluorapatite_R050529: $\mathrm{Ca}_{5}\left(\mathrm{PO}_{4}\right)_{3} \mathrm{~F}$ ]

Fig. 18 - Raman spectrum of bead KB.18.B.63 showing the characteristic bands of fluorapatite $\left[\mathrm{Ca}_{5}\left(\mathrm{PO}_{4}\right)_{3} \mathrm{~F}\right]$.
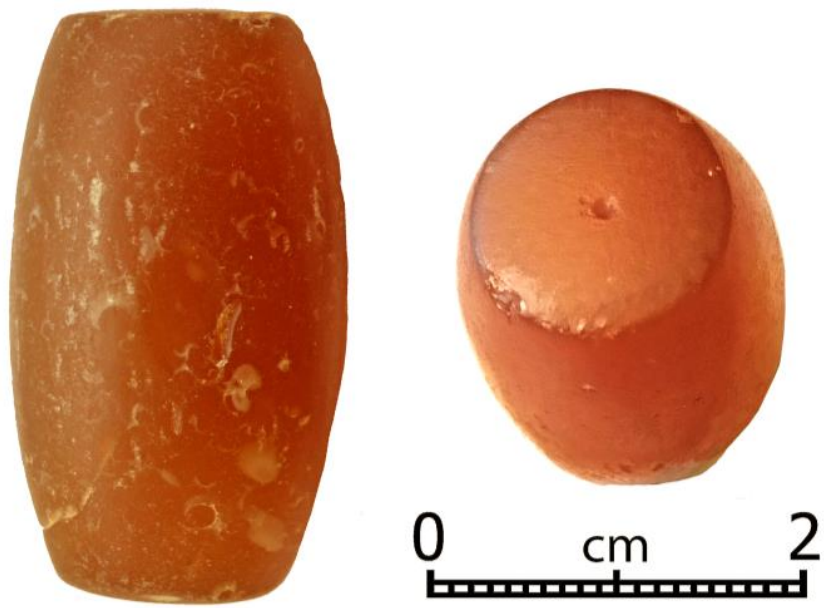

Fig. 19 - Carnelian bead KB.19.B.140, not yet pierced, baked and polished. 


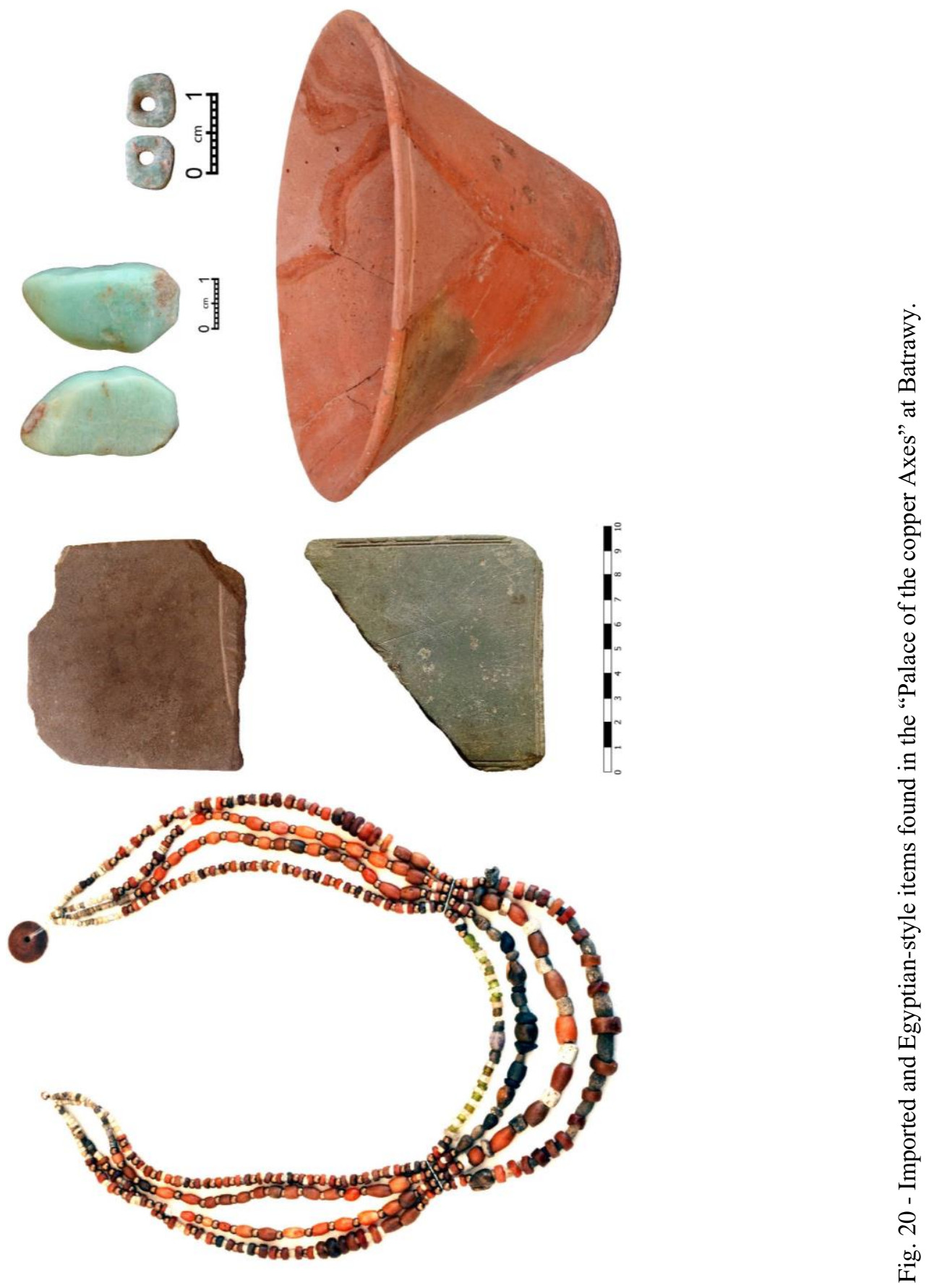




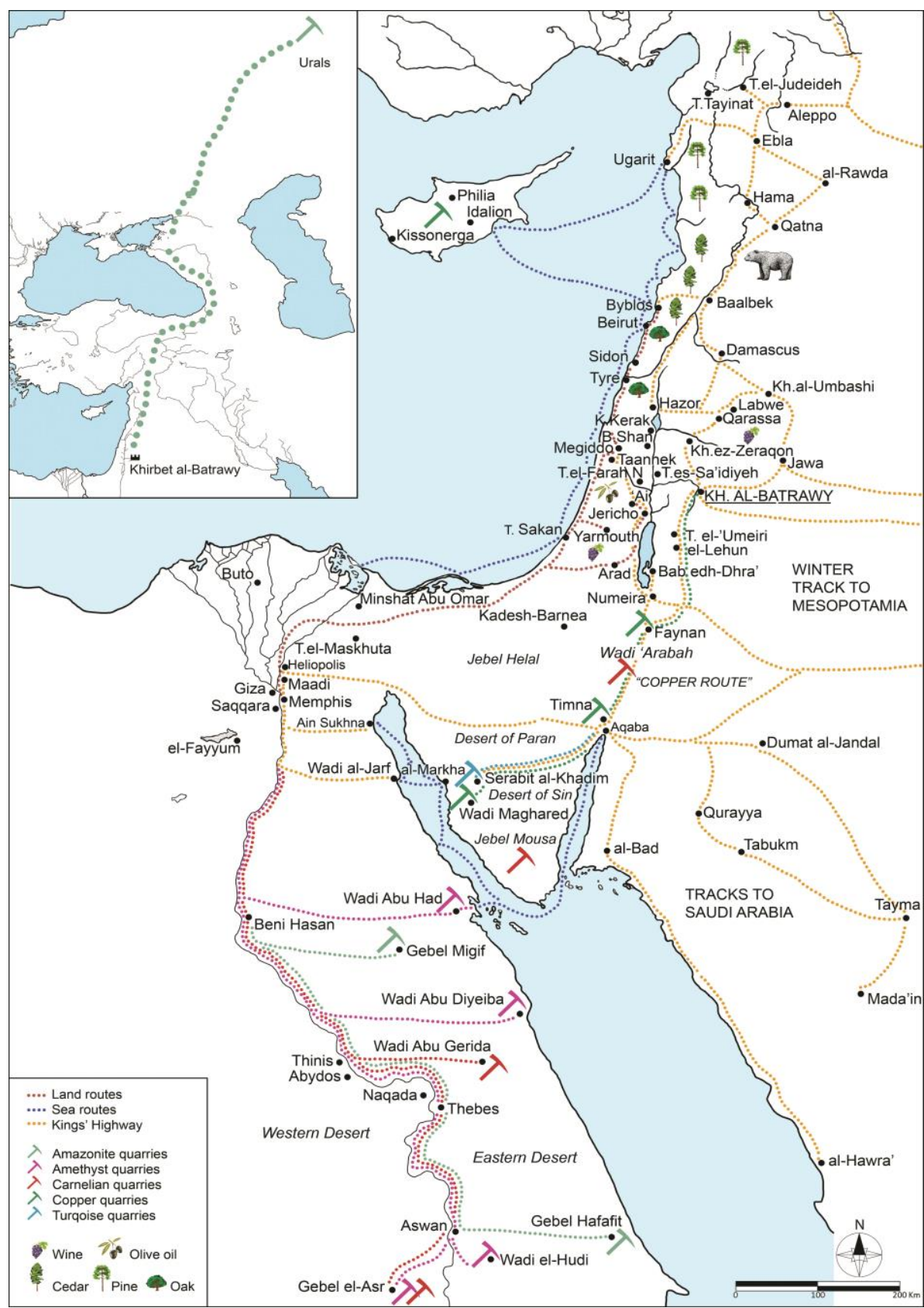

Fig. 21 - Map with supply point for precious stuff and trade routes passing through the city of Batrawy, with the possible northern trade route across Caucasus, Anatolia and Levant. 